\title{
THE EDUCATION ISSUES OF THE CHILDREN OF INTERNAL MIGRANT WORKERS IN CHINA
}

\author{
Shizhan Yuan
}

A Thesis submitted to the faculty at the University of North Carolina at Chapel Hill in partial fulfilment of the requirements for the degree of Master of Arts in Education in Culture, Curriculum and Change Program in the School of Education

Chapel Hill

2014

Approved by:

George Noblit

Xue Lan Rong

Ji-Yeon Jo 
(C) 2014

Shizhan Yuan

ALL RIGHTS RESERVED 


\begin{abstract}
Shizhan Yuan: The Education Issues of the Children of Internal Migrant Workers in China (Under the direction of George Noblit)
\end{abstract}

The education issues of migrant children in China have been a public focus since mid1990s. Due to the restrictions of their Household Registration status, the migrant children have often been rejected by the public schools in the cities, arousing the public questioning about the equality of the public education in China for these children. Up until now, rural migrant students still face discrimination in the urban public school system, and the education problems of migrant children have not been well solved.

This study proved that despite some improvements in the education of the migrant children in the city, there is still a long way to go to improve the education quality and equality for the migrant children.

Key words: migrant children, migrant school, education quality, China 


\section{ACKNOWLEDGEMENTS}

I would like to express my deepest gratitude to my advisor, Professor George Noblit, whose patience and expertise have helped me through the process of developing ideas and thesis writing. I also will never forget his efforts of editing my thesis.

I will also gave thanks to my thesis committee members, Professor Xue Lan Rong, and Dr. Ji-Yeon Jo, for their attentiveness to my work and their patience in providing very helpful questions and comments on my work. I would like to specially thank Professor Xue Lan Rong for providing me with very helpful reading materials.

Last but not least, I thank my parents, for caring, supporting and inspiring me throughout my life. 


\section{TABLE OF CONTENTS}

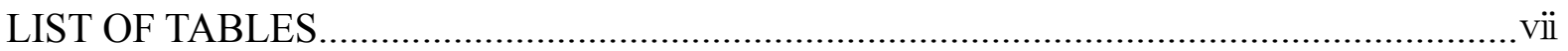

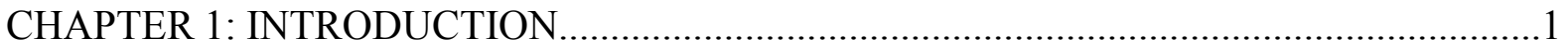

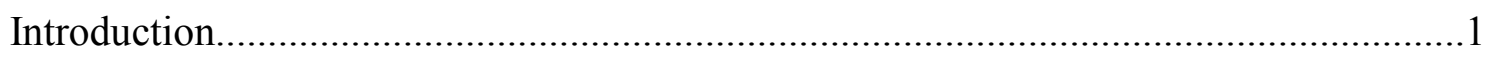

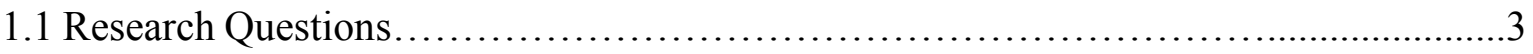

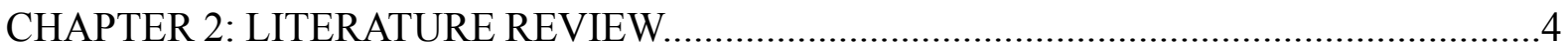

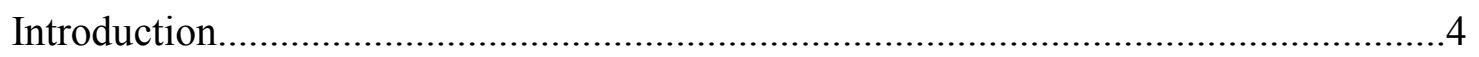

2.1 Historic Background of Migration, Rural Migrant Workers and

Migrant Children in China.....................................................4

2.2 The Educational Issues of Migrant Children.............................................................

2.3 The Migrant Children are Unprotected by the Education Laws...................................8

2.4 The Household Registration System and its Influence on the

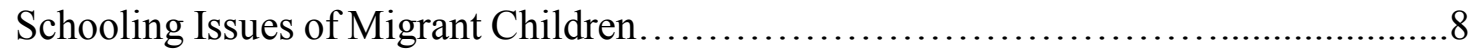

2.5 Financial Obstacles for the Migrant Children to Attend

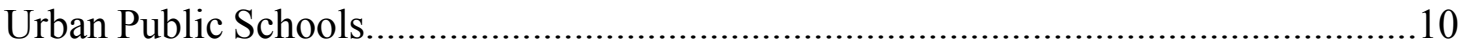

2.6 Administrative Obstacles for the Migrant Children to attend

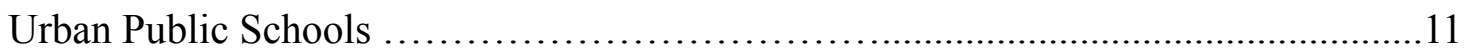

2.7 The Migrant Schools for the Migrant Children....................................................... 12

2.8 The Consequences of Segregation Faced by the Migrant Students

in the Urban Schools................................................................... 14

2.9 Major Challenges for Educating Migrant Children in the Cities...........................17

2.10 Migrant Children are Not Allowed to Take College Entrance Examination

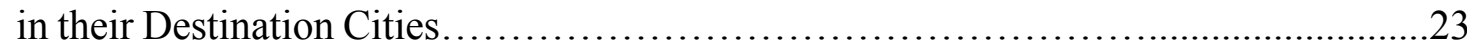


2.11 The Choices of Schools in the Cities for the Rural Migrant Children.

2.12 Laws or Regulations Relevant to the Schooling Issues of

2.13 Decentralized Educational Administrative and Fiscal System...........................38

2.14 Different Cities have Developed Different Solutions to the Education Issues of the Migrant Children.

CHAPTER3: ADOPTING CULLTURALLY RESPONSIVE EDUCATION

(CRE) IN THE URBAN PUBLIC AND PRIVATE SCHOOLS FOR

MIGRANT CHILDREN. .47

CHAPTER 4: CONCLUSION.

4.1 Suggestions for the Future Researchers. .64

APPENDIX 1: TYPES OF SCHOOLS THAT MIGRANT CHILDREN

COULD ATTEND IN THEIR DESTINATION CITIES BEFORE 2006 .66

APPENDIX 2: LAWS AND REGULATIONS RELEVANT TO

THE SCHOOLING ISSUES OF MIGRANT CHILDREN .69

REFERENCES. .75 


\section{LIST OF TABLES}

Table

1. TYPES OF SCHOOLS THAT MIGRANT CHILDREN COULD ATTEND IN THEIR DESTINATION CITIES BEFORE 2006.

2. LAWS AND REGULATIONS RELEVANT TO THE

SCHOOLING ISSUES OF MIGRANT CHILDREN .71 


\section{CHAPTER 1: INTRODUCTION}

\section{Introduction}

The education issues of rural migrant children are a hot topic in China. In recent years, with the increasing number of migrant children arriving in the cities, their education issues have become an important agenda for the governments at different levels. The Chinese government has taken measures to improve the basic education for the migrant children. However, due to its decentralized fiscal and education system, the problems of migrant children education have not been fully resolved. There are still many rural migrant students who cannot attend the public schools in the urban areas. According to Li (2010, p. 175-187), the public school attending rate for the rural migrant children in the urban area ranged from $65 \%$ to $85 \%$. That means that there are still $15 \%$ to $35 \%$ of migrant students who cannot attend public schools in the cities. And 3 years later, according to Du K.W. (2014), the vice minister of Education Bureau of China, in 2013 there were 12.77 million rural migrant children in the cities; $80.4 \%$ of them attended public schools in their destination cities. The rest of the migrant children have to either attend the low-quality private migrant schools in the cities or not attend any school. The school attending rate of the migrant children is still significantly lower than the national level, in 2012, for the whole country, $99.85 \%$ of the primary-school age children attended primary school, $94.37 \%$ of the junior-middle-school age children attended the junior middle school (Chinese Government, 2013).

Realizing the great urgency and necessity of solving the schooling problem of the migrant children in the cities, the central government requires the local urban governments to address 
the schooling problem of the migrant children. Relevant laws and regulations have been made that ask the local urban governments to solve the schooling problem of the migrant children. However, these laws and regulations from the central government have caused the tensions between the central and the local urban government. To absorb more migrant children into their public school system, the local urban governments have to pump extra public education funds into their education system (even if they don't want to). For example in 2012, the Shanghai urban government has invested 543 million US dollars to incorporate the migrant children into its public schools (Yiu, 2014). So absorbing the migrant children into the public school system has added burden to their financial budget of the local urban governments.

The local urban governments and the central governments should work together to solve the schooling problems of the migrant children. The central government should shoulder more responsibility to help the local urban government solve the schooling problems of the rural migrant children in the cities.

Currently, more and more migrant children have been admitted by the public schools in their destination cities. In order to reduce the discrimination towards the rural migrant children in the urban public schools and improve the education quality, Culturally Responsive Education (CRE) should be implemented in the urban public schools and private migrant schools that migrant children attend.

The other discrimination toward the migrant children is that they cannot equally be admitted by the local colleges and universities in their destination cities compared with the local urban children. Up until now most of the migrant children in the city of Beijing and Shanghai still cannot sit for the College Entrance Exam in their destination Beijing and Shanghai and they will have to return to their rural hometown to sit for the exam. Even if a few 
migrant children are able to sit for the College Entrance Exam in the destination cities, they are not count as the local urban students and they have to go back to their hometown where their Household Registration Certificate (Hukou) situate in order to participate in the college admitting procedures. If they do not want to go back to their rural hometown to participate in the college entrance exam, they are only allowed to attend local vocational or technological schools (China Education Online, 2014). The education accessibility of the migrant children in their destination cites is still restricted by their parents' Hukou status.

\subsection{Research Questions}

This study focus on two major issues regarding the education of rural migrant children in the urban area:

(1) To what extent do the migrant children cannot equally get access to the public education resources (e.g. public schools and equal opportunities to be enrolled by the local colleges and universities) in their destination cities compared with the urban children?

(2) What were developments of public policies for the education of rural migrant children in the urban areas from 1996 to 2010 ?

(3) How to use Culturally Responsive Education (CRE) methods to improve the education quality for the migrant students in their destination cities? 


\section{CHAPTER 2: LITERATURE REVIEW}

\section{Introduction}

This part will present the past studies on the educational issues of migrant children, such as the studies of the difficulties faced by the rural migrant children when they attend the public schools in their destination cities, as well as the poor conditions of the private migrant schools. All of the studies mentioned in this part of my thesis indicate that migrant children are not been treated equally in their destination cities, and their rights to receive compulsory education cannot be fully guaranteed even through some measures have been taken by the local governments. Often migrant children cannot attend the public schools together with the local urban children.

It is very important to note that I found most of the researchers choose the private migrant schools of the big cities such as Beijing and Shanghai as their study sites. Studies on the public migrant school are very rare.

In order to clarify important concepts in this thesis, the definitions of migration, migrant workers and migrant children in the context of China will be given.

\subsection{Historic Background of Migration, Rural Migrant Workers and Migrant Children in} China

The term "migration" generally refers to the acts of people who move within national borders (Bi \& Szente, 2010). In 2007, about $10 \%$ of the population or 120 million people in China were internal migrants, most of whom had come to the major cities of the country from the countryside (Kwong, 2011). The term migrant children in China refer to the children who 
were born in the rural areas of China and then follow parents (internal migrant workers) moving to the big cities of China. Their parents work in the cities doing all kinds of labor or drudgery that the normal city dwellers would not do and receive a much lower salary than the local urban workers.

After the 1949, when the People's Republic of China was founded, the Chinese government followed the Soviet Union to implement a centralized planned economy in order to realize industrialization and develop heavy industry. In the rural areas of China, the peasants were forced to form People's Communes and nearly all agricultural products that peasants produced were collected by the government. So before 1976, the farmers in the rural area were restricted to their communes and not allowed to work and pursue a better life in the cities. As China implemented the "Reform and Open up" policy in 1976, it began to allow the peasants to work and temporarily live in the urban area.

In 1980s, the planned economy was abolished, a "household responsive system" was established. This system allowed the farmers to keep agricultural products that they produced in their farmland and allowed them to sell their products in the market. The biggest advantage of this system is that it inspired great incentives and enthusiasm for the peasants to do farming, and greatly improved the agricultural productivity in the rural areas. The rural areas did not need more labor, so surplus labor forces developed in the rural areas.

At the same time the government began to allow the private sector to participate in the national economy. Factories and private enterprises began to appear in the towns and cities. They were mainly distributed in the southeast area of China, and these private businesses created millions of job opportunities. At the same time, some foreign companies also entered the China, opening factories in the south and east seaboard of China in order to make use of its 
cheap labor. The factories built by the domestic or foreign investors are labor-intense industries producing clothes, shoes, furniture, consumer electronic and home appliance, and they are in great needs of cheap labor. So these factories have absorbed much of the labor forces migrating from the rural areas.

According to Zhu (2013) and Xiao (2011), from the first appearance of migrant workers in 1980 s to 2012 , the number of migrant workers had increased dramatically from zero to more than 260 million. The Chinese Academy of Social Sciences has reported that the rural migrant workers mainly work in manufacturing, export-oriented industries, service industries, or construction industries (Xiao, 2011). The Chinese GDP has grown rapidly to 8 trillion US dollars in 2012. These migrant workers made great contributions to the development of Chinese economy, but they receive the lowest salaries in the cities. For example in Beijing, the average monthly income of migrant workers is $2500 \mathrm{RMB}$, barely a living wage in the cities (Beijing Youth Newspaper, 2012), while the people's average income in Beijing of 2012 is 3,039 RMB per month (China News Network, 2013). In Canton Province, which has the largest number of migrant workers (26 million) in China, the average monthly income of its migrant workers is $40 \%$ less than the local urban dwellers, although they spend $50 \%$ more time on their work than the local urban workers.

Though the government gives poor peasants the freedom to work in the cities, it did not fully guarantee their rights of free migration. Because of the restrictions of Hukou (the household registration system), they cannot enjoy the rights and social benefits shared by the urban household registration holders. These social welfares include healthcare, education rights, retirement and employment insurance as well as employment rights to jobs affiliated with government agencies at all levels. 
In 1984, the government allowed the rural residents to work and temporarily live in the city and purchase food in their working place. However, because of their household registration status, they cannot enjoy other welfare and services in the cities, such as the healthcare, social insurance, etc. Moreover, their children cannot participate in free compulsory education in the urban areas. In addition, although the Chinese government saw the exportoriented manufacturing industries as a pillar of Chinese economy and admitted that migrant workers play an important role on those industries, when the legal rights of migrant workers were violated by their employers, the local urban governments often turned a blind eye on it. Reports have been rampant in the public media that rural migrant workers often suffer from unequal treatment in their work place, such as working overtime without overtime payment, pay being withheld, and even physical abuse, even though they do the most dangerous, dirty and difficult works in the cities (Xiao, 2011).

\subsection{The Educational Issues of Migrant Children}

The education issues of the migrant children in China have long been a concern by the researchers worldwide. And many studies have been conducted in the big cities of China, for example, Zhang \& Lu (2004), Goodburn (2009) and Kwong (2011) have the capital city of China, Beijing, as the place of their studies. Fu (2001) studied the education issues of the migrant workers in the Chengdu-in the southwest of China. Xiao (2001) investigated the schooling problem of the children of migrant workers in the south China cities of Guangzhou and Shenzhen, and Zhu (2001) studied migrant children in megacity of Shanghai in the east of China. 


\subsection{The Migrant Children are Unprotected by the Education Laws}

Migrant children face unequal treatment in the city, and the most serious issue is that they have been deprived the rights to receive the legal Nine Years Compulsory Education in the cities. In China, the government provides free nine years of compulsory education for the children who reach the schooling age (5-6). Such low cost education was based on the 1986 Compulsory Education Law of China, and this law stipulates that the Nine Years Compulsory Education is administered by the local authorities under the leadership of the State Council. Governments of all levels receive funding from central authorities and the local government must use their own local budgets to provide education only for the local students who are registered as the residents of their locality (Xia, 2001). However, this law failed to consider the education issues of the migrant children from the rural areas who temporarily settled in the city with their parents and it does not address the equal rights that the migrant children from rural areas to receive free or low cost nine years compulsory education in the city. This is because they come from the rural area and they are not the local residents, and the Compulsory Education Law only asks the local government to use their own budget to provide education for the local students. So if the migrant children want to attend schools in the city area, they must pay for their own education in the city.

\subsection{The Household Registration System and its Influence on the Schooling Issues of Migrant Children}

The Household Registration System (Hukou) was established in 1954, when the Chinese government began to implement planned economy ( $\mathrm{Li}, 2013)$. The major benefit of Hukou is that it makes easier for the government to manage the migration of its population and maintain public security and stability, especially after the ending of Chinese civil war (1946-1949). The 
other benefit is that it serves the planned economy because it requires both urban and rural citizens to stay and work in their place of origin. Internal migration has been strictly restricted. With the implementation of the planned economy, the leaders of China believed that they could establish a communist Utopia in China. The products produced by different economic sectors would be equally distributed to its citizens, and central government dominated this distribution. Markets were abandoned. The residents cannot use money to buy food, clothes and other things in the market without coupons issued by the government to purchase these products. The coupons were not equally distributed in the city and urban areas. The urban residents get more, while the rural residents get less. The Household Registration (Hukou) System in China gives each Chinese citizen access to social products, social welfare, and maintains a balance of the social resources. China uses Hukou system to divide Chinese citizens into urban and rural residents, and separating the rural and urban residents in the aspect of accessibility and distribution of the social resources, products, welfare and services since 1950s (Xiao \& Fu, 2011). Because of the existing economic disparities between urban and rural as well as East and West, the East urban dwellers enjoy a much better distribution of social resources and products than the rural Western residents.

Although the Chinese government, since 1980s, abandoned the planned economy, adopted a market economy, and pushed forward economic and social reform, for some reason, its social and economic reform has not been thorough. The Hukou has not yet been abolished. When rural citizens who have rural Hukou come to the cities, they still cannot enjoy equal social welfare and benefits to that of the urban citizens. The children of migrant workers (migrant children) cannot attend the same urban public schools for the local urban students.

The Hukou is the internal passport system of China (Yiu, 2014) and it is the biggest 
barrier of migrant children receiving equal education opportunities. In 1986, the Chinese government implemented the Compulsory Education Law. This law required the local governments provide the free 9 years compulsory education for the school-age children. However, this law stipulated that the children should attend the nearest neighboring school to where their Hukou are situated. The children of the rural migrant workers who follow their parents come to the cities cannot attend the public schools in the cities, because their Hukou is still in their home villages. So technically these rural migrant children are not entitled to receive compulsory education in the cities and they are only allowed to attend the rural schools in their hometown. Thus, due to the restrictions of their Hukou, migrant children are denied access to the urban public schools.

The result of the Hukou restriction is that the children of normal urban residents with their Hukou registered in the city areas can attend high quality public schools in the city center, while, the rural migrant children without an urban Hukou cannot attend high quality schools in the city center together with local urban children. Xia (2006) mentioned that a person's Hukou status determines his or her access to state services. Under normal circumstances, a person with rural Hukou status is not eligible for state service in the urban areas (including attending public or state schools in the city) (Montgomery, 2012).

The Hukou is primarily inherited from one's parents at the time of birth. Even if a child was born in the city, as long as their parents are rural Hukou holders, the child's Hukou is still registered in the rural area. Thus the child still cannot enjoy the state services shared by the city residents.

\subsection{Financial Obstacles for the Migrant Children to Attend Urban Public Schools}

In order to attend the public schools in the urban areas, the rural migrant children are 
required to pay fees from which most urban children are exempted. According to Goodburn (2009) and Mok et al. (2011), in 2002, in the capital city-Beijing, the local public schools charged rural migrant children a series of fees. These fees included an education compensation fee, a temporary schooling fee (placement fee), a miscellaneous fee, and a sponsor fee on top of their tuitions. When all of these fees were added together, they could range from $4000 \mathrm{RMB}$ to $6000 \mathrm{RMB}$ a year. It is a large sum of money for a lot of migrant workers families with average annual income in 2002 of no more than 10,000 RMB.

Fu (2011), Bi and Szente (2009) and Xia (2006) have mentioned that the migrant children in the city who want to attend the high quality public schools in the city center have to pay so called "Temporary Schooling Fee (jie du fei)" which local urban students were exempted from, and as well as various donations and surcharges. These charges were far beyond what the normal migrant workers family could afford. Such fees vary based on the reputation and location of the schools and they can be as high as 50 thousand yuan (equivalent to $\$ 7,500$ ) per year (Bi \& Szente, 2009). Thus many migrant children are prevented from going to the public schools because their family cannot afford this expense. Actually, it is really an extremely large amount of money for a family whose average income is below 1,000 Chinese yuan (166 US dollars) per month in 2001 (Zhu, 2001). Even when the new Compulsory Education Law came into effect in 2006 stressing the equal education rights between the local students and migrant students, many schools in the urban areas still charged migrant students the illegal temporary schooling fee (Xia, 2006 \& Goodburn, 2009).

\subsection{Administrative Obstacles for the Migrant Children to Attend Urban Public Schools}

Migrant children also need to produce a series of certificates in order to be enrolled in the urban public schools. In addition to the Household Registration Certificate, the migrant 
children's families also need to have identification cards, temporary residence permits, working permits, health certificates for the parents, a population planning certificate, a social insurance certificate, and guardianship certificates of parents, or birth certificate, as well as a health certificate and immunization record for the child (Bi \& Szente, 2009).

Similarly, Goodburn (2009) mentioned that migrant parents who did not have the required identification card, temporary residency permit and work permit, or whose children was born "out of plan" (unauthorized by state population planning policies) were unable to enroll their children in any state school. Some good state schools in Beijing are even stricter in not enrolling rural migrant students. They asked for as many as 8 documents including an identification card, a temporary residence permit, a health certificate of parents, a population planning certificate, a social insurance certificate, a birth certificate, and a health certificate of the child. It is obvious that almost none of the migrant worker families could get all of the 8 documents.

The restrictions are not just Hukou. The migrant children also face other administrative barriers to education. They have to go through a series of complex bureaucratic procedures in order to be enrolled in the urban public schools.

\subsection{The Migrant Schools for the Migrant Children}

Many migrant children have to attend migrant-run schools until they reach the age of 12 before they will be sent back to their hometown in the rural areas to attend schools there. These migrant-run schools are normally unlicensed and the conditions are very poor. They are founded by the private and for-profit groups, and they do not follow the standards required by the education ministry.

I found most of the studies on the education issues of the migrant children focused their 
attention at those private-run illegal schools for the migrant children or the private migrant school. For example Goodburn (2009) studied those underground "black schools" for the migrant children in Beijing, and she found that these schools try to follow the state curriculum as much as possible but the biggest problem is a lack of high quality school teachers. Many teachers in the migrant schools had educational levels only slightly above that of their pupil. As mentioned by the Kwong (2004), a study of 114 migrant schools in Beijing found over 65\% of teachers had no teaching experience and some had been construction workers, street hawkers, cooks, vegetable farmers, childcare workers and janitors. So it is obvious that many teachers in the migrant schools do not have the necessary qualifications to teach students. Also many migrant schools do not have facilities to offer some non-examination subjects such as PE, music and arts. The private migrant schools serve a large number of migrant students but the infrastructure is very poor. As Kwong (2011) mentioned in 2000, there were 300 migrant children's schools in Beijing with almost 80,000 migrant children attending and in 2008 about 134,000 students attended migrant schools. However, those migrant schools are often housed in abandoned warehouses, dilapidated buildings or even on open land. Some have no playgrounds, others no running water, and usually 50-80 students huddle in one classroom with poor lighting. It is surprising that the migrant children almost have never complained about the poor facilities in the private migrant schools. They seems to be accustomed to the poor conditions at home, as well as to the schools' poor physical environment. In many studies, the migrant school is described as a type of private-run, low-quality and inadequately funded schools without permanent addresses (Xiao, 2011).

As I mentioned beforehand, due to the poor facilities and extremely low education quality, most of the private migrant schools are on the verge of been completely shut-down. Some 
migrant schools do survive, and they have to frequently change their school locations in order to avoid government inspection (Kwong, 2004). Without a stable environment, it will be extremely difficult for the migrant children to study.

\subsection{The Consequences of Segregation Faced by the Migrant Students in the Urban Schools}

The rural migrant children in China do not have many choices for schooling in the cities. Most of the migrant children attend migrant schools (the migrant schools may either be private or state-run) which are specially reserved for them, and in many cities such as Beijing and Shanghai, only $58 \%$ to $66 \%$ migrant children who have Household Registration Certificate of their destination cities or manage to get resident and working permits are eligible to be enrolled by the local normal public schools mixing with local urban students. In the province of Guangdong, as mentioned by $\operatorname{Li}(2010)$, only 170,000 or $40 \%$ of the migrant children are enrolled in the normal public schools together with other local urban students. The migrant schools enroll almost only migrant children. Few local urban students attend them. Thus, the migrant children who attend migrant schools in the cities are faced with social segregation. They have no chance to communicate and interact with the local urban students, which prevents them from integrating into the urban society.

Moreover, the migrant schools and normal public schools are two very different social environments. These two different environments likely engender different consequences for academic performance, social interaction and psychological well-being. The ordinary public schools have better facilities, teaching staffs, curriculum, teaching and learning materials, while those segregated migrant schools are much more likely to have overcrowded classrooms, employ poor performing teachers, and provide a less nurturing atmosphere (Lu \& Zhou, 2013; 
Postmes \& Branscobe, 2002). Thus, the migrant children in the ordinary public schools tend to have higher achievement, higher self-worth, and better social competence (Lu \& Zhou, 2013; Postmes \& Branscobe, 2002).

Lu and Zhou (2013) utilized segmented assimilation theory to analyze the school segregation experienced by the migrant children in the cities. They pointed out that the desegregated public schools offer superior connections to the mainstream society and that better educational resources would promote social assimilation and help the migrant children integrate into the mainstream society of their destination cities. Meanwhile, the segregated migrant schools have an unfavorable school environment and a more disadvantaged population, subsequently slowing or even halting the assimilation process. By conducting 3 longitudinal surveys with 1,259 migrant children of from 12 public schools and 7 migrant schools in 2006 and 2007, Lu and Zhang (2013) found that migrant children in the segregated migrant schools were more disadvantaged in their psychological well-being. However, through 2 years of the study, the psychological-health scores of the migrant children enrolled in the public schools were able to quickly catch up with and approach to that of the local urban students, due to the opportunity for social integration and interaction between the migrant students and local urban students. In addition, the better social and environment provided by the public school would also benefit the academic performance of migrant children. As the study conducted by Lu and Zhou (2013), the migrant children in 12 public schools and 7 migrant schools of Beijing. These students did more poorly on both math and language tests than urban children. They also found that the migrant children in the migrant schools performed more poorly than either the migrant children who studied in public schools or local urban students in public schools. Further, migrant children in public schools performed much 
better than their counterparts in the migrant schools and seemed to catch up with the native urban students in the public schools overtime.

Poor and low-socioeconomic status children on average perform significantly less well than non-poor children on numerous indicators of academic achievement including test scores, grade retentions, course failures, placement in special education, high school graduation rate, high school dropout rate, and completed years of schooling (McLoyd, 1998). Generally speaking, the migrant children of China are poor and low-socioeconomic status children in their destination cities. According to the McLoyd's (1998) theory, the migrant children of China may perform less well than the local urban students, who are relatively richer and higher socioeconomic status, and have higher test scores, higher school graduation rates, lower school dropout rates, and more completed years of schooling.

As indicated by Ferguson, Bovaird, and Mueller (2007), school readiness reflects a child's ability to succeed both academically and socially in a school environment. School readiness encompasses multiple areas including physical well-being, appropriate motor development, emotional health, a positive approach to new experiences, age-appropriate general knowledge and cognitive skills. Because of the segregation in the migrant schools, as the study conducted by the Zhou and Lu (2013) indicates, migrant children in the migrant school are more likely to suffer from loneliness than the migrant children in the desegregated ordinary public schools or the urban local children. Their study also indicates that the migrant children in the segregated migrant schools also perform worse in language and math tests than migrant children in desegregated public schools. So, Zhou and Lu's (2013) study informs us that migrant children in the segregated migrant schools tend to have a much lower level of school readiness than those migrants in the desegregated public schools or native urban students. 
So as we can see from above, the best way to solve the schooling issues of the migrant children is to include them in the urban public schools. The segregated migrant schools (either private or state-found) cannot create a good social environment for the migrant children to integrate in the local urban society, and cannot improve the psychological health of the migrant students. Migrant children in the segregated migrant school tend to feel lonely and do not have native friends from the local cities. We should improve the academic performance of the migrant children in the cities, and at the same time, take care of their mental and psychological health, and promote the social integration of the urban people and the rural people.

\subsection{Major Challenges for Educating Migrant Children in the Cities}

According to the research conducted by Mok et.al. (2011) and Wang \& Holland (2011), there are several major challenges to the migrant children attending schools in their destination cities.

The most obvious one is the discontinuity of schooling experience due to the high mobility of migrant children. Migrant children belong to the floating population. Their parents change jobs frequently, and they will follow their parents to go to different cities, and attend schools in the cities where their parents work at (Mok et.al, 2011). As mentioned by Wang \& Holland (2011), migrant children were more likely to change schools than local urban students. Further, the mobility rate of migrant children in migrant schools was higher than the migrant children in the public schools. The percentage of migrant children enrolled in the migrant children schools for two years or less was as high as $71 \%$, while the percentage of migrant children enrolled in the public schools for two years or less was 35\%. Moreover in the public schools, the mobility of migrant children was much higher than that of local children.

The direct consequence of the high mobility of migrant children is that they may have 
difficulties in catching up with the coursework. According to the Wang \& Holland (2011), if migrant children came to a public school of the destination cities as early as 1 or 2 grade, they would likely have no difference in their learning attitudes, abilities, and habits from local children, and so they would have little difficulty adjusting to the new learning environment. However, if they come to a public school in $4^{\text {th }}$ grade or later, they may fall behind the local students in their course work and their learning attitudes, abilities, and habits.

Schools in different regions vary in their curriculum, quality of teaching staffs and facilities. The quality of education varies across different regions of China. The different learning experiences and school environments may create great difficulties for migrant children to adjust to a new urban school. In China, a student's grade level is dependent on his age. For example, a 6 year old child should attend the $1^{\text {st }}$ grade and 7 year old should go to grade 2. However, due to poor performance, learning habits and abilities of migrant students, they cannot attend their age-appropriate grade at an urban school. So many migrant children from the rural areas cannot compete with their same age and grade counterparts in the public schools. As mentioned by Wang \& Holland (2011), in Shanghai, a good number of $5^{\text {th }}$ and $6^{\text {th }}$ graders in the schools were at least 2 years older than the normal ages for those grades.

In order to solve the discontinuity of schooling experience, both migrant schools and public schools have taken different measures.

(1) Curriculum material and textbooks.

Migrant schools in the cities will use the textbook used by the migrant children's hometown, and do not use the textbooks used by the urban public schools. For example, as mentioned by the Chen and Liang (2009, pp.127), the migrant schools in Beijing use textbooks prepared by the People's Education Publishing Company, which have been widely used in 
other parts of the nation and prepares students for general entrance examinations for most of the country. These migrant schools do not use the reading materials prepared exclusively for the public schools of Beijing and Shanghai. The migrant children may not be able to stay in one school in one city for very long time, they tend to follow their parents and move to other cities or go back to their hometown. Thus they tend to transfer to different schools frequently. So using a universal-standard textbook (published by People Education Publishing Company) could reduce their discomfort when they transfer back to the schools of their hometown.

Migrant children have to return to their hometown to take the College Entrance Exam. So adopting the textbook published by the People Education Publishing Company could help migrant children to prepare for this very important exam.

(2) The urban governments try to include more migrant students into their public school system. But many migrant children in public schools will be assigned to a separate class with other migrant children and apart from local urban students.

This measure has brought strong criticism. For example, as mentioned by China Central Television (2006), in 10 public schools of Wuhan city, all of the rural migrant students were assigned to a separate class. The superintendent of the Wuhan Education Bureau said "this practice is only an experiment and used to help rural migrant children overcome their language barriers and their low self-esteem when they communicate with the local urban students". He also mentioned that migrant children need to go through a stage of adaptation before they could be included in the normal classes with local urban students. The "Nan Fang Zou Mo" newspaper criticized this practice and compared this to the historical separated bus compartment for the African Americans decades ago.

Actually in the US, there are ESL classes in the public schools for the students who 
cannot speak English, the ESL classes are to help ESL students master the English quickly and catch up with normal students in their school course work. However, the rural migrant children in Wuhan do not have any language barrier when they communicate with the local urban students, because both migrant students and local urban students speak the Chinese language. So, the excuses given by the superintendent of Wuhan Education Bureau for establishing separated classes for migrant children do not hold water. The migrant children should not be separated from normal students in the public schools.

Separating migrant students from the normal urban students also resemble the U.S. practice of tracking students according to their different reading and math level or their academic ability at a certain point in time. Actually, the practice of tracking students is also very common in China. In almost every school of China, students are often be assigned to key classes and normal classes based on their academic performance. The proponents advocate tracking, arguing it may be easier for the teachers to teach relatively homogeneous classes and that it may be unrealistic for everyone to master the same curriculum. The proponents also believe that students would feel more comfortable and learn better when they are grouped with peers of similar abilities (Education Week, 2004). However, tracking migrant students into a special class actually does not bring any comfort to the migrant children and their parents, and it will hurt their feelings instead.

Even in recent years, this problem continued to exist, as reported by Kunming Daily Newspaper (2014), a representative member of National People's Congress of Yunnan Province mentioned that migrant workers spared no effort to get their children to attend urban public schools. Yet, when they finally managed to get their children into the public schools, they found their children still faced discrimination. For example their children were often 
placed in a separated class or do not have official school-record in the urban public schools.

This congressman mentioned that the separation will hurt the feelings of the migrant children and their families.

So, separating migrant children to a special class would not enable their adaptation to the urban public school environment. And on the contrary, it is a new form of discrimination for them.

(3) The governments of the cities shut down many "unqualified" private migrant schools.

Many migrant children still cannot attend public schools in the cities and instead they have to go to underground private migrant schools. These illegal migrant schools have brought about many challenges to the local cities. As I mentioned beforehand, these migrant schools have very poor facilities, do not have adequate teaching staffs, and could not meet the basic national standards. Different governments of cities have different attitudes and have taken different measures towards these private migrant schools. Whatever measures have been taken by different urban governments, many private migrant schools have been closed by them.

The local government has a political consideration regarding the closing of the private migrant schools and completely solving the schooling issues of the migrant children in the destination cities. As mentioned by Kwong (2004), the local urban governments are afraid that resolving the problem of education would encourage more migrants to move into their jurisdiction and bring with them more social problems. The official "The China Education Development Yearbook 2010", it mentioned that:

the biggest concern regarding the incorporation of migrant children into public schools is that if the doors are fully opened, a large number of the rural children, who are not the children of migrant workers, will swarm into the cities to take advantage of the policies for 
the migrant education. Therefore necessary thresholds must be implemented, such as certain certificates or documents, a fixed number of years of residence in the city, and a stable job (Li, 2010, p. 186).

From above we can see that the Chinese government at different levels have to consider the issues of social benefit allocations between the rural and urban dwellers. They do not want rural people to absorb too much of the urban resources such as high quality urban education or the urban dwellers will complain. But on the other hand, we should consider why so many migrant children want to attend the private migrant school in the cities even if those schools are in a very low quality. The answer is clear. The rural areas are extremely poor and rural public schools are of the worst quality of all even compared with those illegal migrant schools in the cities.

The decentralized administrative and fiscal system has made the disparity between the urban and rural area grow larger (Yu, 2004, p. 93-100). The urban areas may have sufficient funds to finance the development of their urban education, while the poor rural areas do not have money to improve their education and infrastructure. According to Yu (2004, p.95), in 1999 , the governmental public education fund for each rural student is only equals to $60 \%$ of the public education funds for each urban student. The superior education quality of the urban areas attracts millions of rural migrant children to the school in the cities, even if they can not attend the best public schools in the cities.

Both central and local rural governments fail to improve the education condition in the rural area. Thus, they should be held responsible for the large migration of rural students to the cities.

As mentioned by Ruan (2014), (Ruan is a migrant worker in Yunnan Province, he is also a 
representative member of National People's Congress of China), through research, he found that even if migrant children managed to attend the public schools in the cities, they can only go to the public schools with the poorest facilities in the cities or in the suburban areas of the cities. The local urban governments seems to have no interest in completely solving the schooling issues of the migrant children.

\subsection{Migrant Children are Not Allowed to Take College Entrance Examination in Their Destination Cities}

The most important examination for the students in China is definitely the College Entrance Examination. As the only gateway to the tertiary education for most of the high school students in China, this exam will stream high school graduates into different professional and vocational tracks as well as different levels of higher education. However, this exam stratifies the population.

Due to the restrictions of their Hukou and the discriminations of the local urban governments, most of the children of migrant workers cannot sit for the college entrance examination in their destination cities, and they have to return to their place of origin to sit for the exam. As mentioned by Yuan (2012), the ex-Minister of Education of China, migrant children and their parents must meet at least 3 requirements (三大准入) if they want to sit for the College Entrance Examination in their destination cities: (1) the parents must have stable jobs, stable income, paid a variety of social insurances, and have lived in the cities for a long period of time; (2) The migrant children themselves must have attended in the urban public school for certain consecutive years; and (3) The parents must work for the industries that their destination cities really need. Furthermore, each city was allowed to develop their own regulations for the migrant children to attend the college entrance exam in their destination 
cities (Chinese government, 2012).

This regulation aroused wide criticism from the public, Liu (2012) criticized the policy as only protecting the interests of the native urban dwellers, and neglecting the education rights of migrant children. The floating migrant workers change their job frequently, and their salaries fluctuate drastically depending on their working places. Further, they may move to different working places. As a result, almost none of the migrant children could meet this standard. Actually this regulation made it almost impossible for the rural migrant children to sit for the exam in their destination cities. Ye (2012) denounced the privileges of the urban students, he said "why did the urban citizens have the privileges? And why did not the rural students have the rights that they deserved to have? The urban citizens of Beijing and Shanghai have enjoyed the privileges for many years, why should we continued to allow them enjoy their privileges? Are the migrant children and children from rural areas not the citizens of China? Why shouldn't we provide the migrant children equal treatments in the cities?"

As mentioned by Xinhua News Agency (2014), until 2013, of 12.77 million migrant children in the cities, only 4444 migrant students nationwide were allowed to take the examinations in their destination cities in 2013. The percentage is too small. The Minster of the Education compromised for the interests of native urban dwellers and sacrificed the interests of the migrant children in the cities. In my opinion, this is the biggest discrimination faced by the migrant children.

The native city residents enjoy better education resources such as better-equipped schools, colleges, universities, high quality teachers, and most notably, in some big municipal cities such as Beijing and Shanghai, they have special policies to allow more local students to get into good local universities. All of the colleges and universities in the cities usually enroll a 
higher percentage of the local urban students than the students from other provinces and rural areas. Thus, the local city students can get lower grades in the College Entrance Exam and still be admitted by the colleges and universities of their city. However, the out of province or out of city students will need much higher scores in the College Entrance Exam to get into the same colleges and universities.

The rural migrant workers from other places cannot enjoy this benefit even if they have lived in the cities for a long period of time, because their parents are not likely to have stable jobs, stable income, pay a variety of social insurances or work in the industries that the cities need. The urban education ministries categorized the migrant children as the people from outside, preventing them from enjoying the benefits of university enrollment shared by the local urban students. So the migrant children have to go back to their hometowns to sit for the exam and generally need to get a higher score on their exams than the urban students in order to be admitted by same universities.

The local urban governments are not interested in solving the issue of the college entrances examinations for the migrant students. If they allowed the rural migrant students to take the exam in the cities of Beijing and Shanghai, it would encourage more rural migrant students to come to take the exam in these cities. This would make the college enrollment more competitive. Many rural migrant students would be able to be enrolled by high quality local universities, and thus many local students would lose the opportunities to be enrolled by the high quality local colleges and universities. The vice Minister of Education, Du Y. B. (2012), mentioned that:

In order to solve the College Entrance Exam problem of migrant children, we should not only consider the needs of these rural migrant students, but also not influence the 
interests of the local urban students. (Du, 2012)

Actually, most of the cities only consider the needs of the local students. They almost have no interest in considering the needs of rural migrant children in the cities. For example in Beijing, although the city in 2013 began to allow some of the migrant children who met their requirements to sit for the college entrance examination there, the migrant children faced with great discriminations when the local colleges and universities enrolled students. Even if the migrant children get very high scores on the exam, they are not allowed to be enrolled in the bachelor programs of the universities. Instead they are only allowed to attend the low or medium level vocational or technical schools. In Shanghai, the plight of the migrant children is a little better than those in Beijing, for it allowed minimal number of migrant children whose parents met the special requirements sit for the exam in Shanghai and enjoy the equal college enrollment opportunities. However, for the vast majority of the migrant children whose parents did not meet the requirements, like in Beijing, they were only allowed to attend low-level vocational or technical schools regardless of their exam scores (China Education Online, 2012).

It is very interesting to note that the China's practice of allocating the rural migrant children to the vocational and professional training institutes is very similar to the US' practice of Black education after the Civil War in the US history. The Tuskegee institutes focused on cultivating practical vocational and trade skills of the African Americans, and this practice brought severe criticisms from many famous African-American as well as educationists such as W.E.B. Dubois (College View, 2014).

Up until today, China still followed this discriminatory practice by allocating its migrant children to the vocational and technical schools. What the governments of Beijing and 
Shanghai really want to do is to train those rural migrant children into a new generation of the migrant workers who will work in the labor-intense industries (sweat factories) in order to continue to exploit cheap labor forces in the future. So the Chinese government actually treats the rural migrant workers and their children as "cows" which can be "milked" continuously by their destination cities without giving them the benefits that they deserve to get.

Solving the schooling problems of migrant children is a challenge for both central and local governments. The central government needs to regulate the internal migration of its urban and rural population, reducing the negative impact of the internal migration on the social order. At the same time they need to insure social equality and a balance of allocation of social benefits and welfare between the urban and rural people (such as public education). The destination local urban government needs to absorb more migrant workers to develop its economy. It should, at the same time, guarantee their rights for access to the social benefits and welfare in the city as well as guarantee their children's rights to access to high quality urban public education.

\subsection{The Choices of Schools in the Cities for the Rural Migrant Children}

Due to their marginalized identification status and the restrictions of their Household Registration, rural migration children face limited school choices in the urban areas. According to Xia (2006), rural migrant children can only attend 5 types of school in the urban area: (1) public schools which charge high additional fees (temporary schooling fees, placement fees, donations, and so on) on top of their tuitions; (2) government approved, and expensive, private schools; (3) schools set up by the governments of the sending areas in the receiving cities; (4) schools set up especially for migrant children by government in the receiving cities; and (5) migrant children's schools set up by private enterprises. (See Appendix 1: Types of the schools 
that migrant children could attend in their destination cities before 2006)

None of these schools are convenient for the migrant children, and each type of school has different kinds of problems which make the schooling experience of migrant children undesirable. For the public schools which charge high additional fees (category 1), many migrant children cannot attend it due to their family economic background. As I mentioned, since the average income for the migrant children's families is only 10,000 RMB per year in 2002 and the surcharges of these public schools could be as high as 4,000 to 6,000 RMB a year, the normal rural migrant families could not afford their children's schooling in the urban public schools. However, the advantage of this type of school is that the majority of the students are local urban students, and facilities of this type of the school meet national standards, and the teachers are professional and experienced. If a migrant child could be admitted by this type of public school, it could allow an equal educational opportunity in the cities since the migrant child attends the school with local urban students.

The government approved, expensive, private schools (category 2) are not designed for the rural migrant children. They were actually built for the minor aristocratic class in the urban China. The fees charged by this type of private school are highest and the facilities of the expensive private school are the best. Almost none of the migrant children families can afford this type of school. Even the common local urban families could not afford them.

The schools set up by the governments of the sending areas in the receiving cities are semi-official and set up under the Temporary Act on Migrant Children's Education 1998. This act stipulates that the governments at both the migrant origin and destination have the responsibility of providing education to migrant children (Chen \& Liang, 2007). This type of school is not usually successful because the migrant workers come from poor rural areas, and 
their native governments usually do not have sufficient funds to support schools in another place. For example, in 1990s, the Maqiu Town of Nanchang County of Jiangxi Province used to send 14 teachers to Wuhan city in order to help 380 migrant children from Jiangxi Province receive education in the migrant schools. The Jiangxi Province spent 50,000 RMB to pay for these teachers' salaries and living expenses in Wuhan city (Mok, et.al, 2010). Asking the governments of the original rural place to provide education for the rural migrant children in the destination cities is only a provisional measure, because of the expense as well as the difficulties of coordination and communication between the original and destination governments. This kind of practice cannot be implemented on a large scale. The schooling issues of the rural migrant children should be solved by the destination cities, because migrant parents have contributed to the local economy by providing services and paying taxes, and the local urban government should have an obligation to provide rural migrant children with education (Kwong, 2004). At the same time, because of poverty and limited budgets, the original rural governments usually do not have sufficient funds to support their children receiving the education in the cities.

For the private schools set up by the migrant workers themselves, the facilities, the teachers and the teaching itself would not meet the standards required by the Ministry of Education. As mentioned by Fu (2011) and Rural Education Program (2014), the quality of facilities in migrant schools are mostly very poor especially compared to urban public schools. These private migrant schools were located in places that are not typically used for education purposes such as abandoned warehouses and factory grounds. Many have poor lighting, heating, ventilation and sanitation. A number of schools do not even provide drinking water, restrooms, and a playground. 
The quality of the teachers in the private migrant schools is much lower than the teachers in the public schools. As mentioned by Fu (2011), the teachers in the private migrant schools of Chengdu city often come from weak education background: $66 \%$ had received senior middle school and secondary school education, while $7 \%$ of them only had a junior middle school education. However, most of public schools teachers had an at least a college degree and had received teachers' training. Another study by the China Youth Newspaper (2012) mentioned that many teachers of private migrant schools in Beijing are part-time teachers who have not received teachers' training and did not receive a high salary. The average salary for the teachers in the Beijing migrant schools are from 1800 to 2000 RMB per month, which is significantly lower than the teachers in the public schools. And because of the paucity of the teaching staffs in the migrant school, many teachers are required to teach 2-3 school subjects which is a heavy burden for them.

The curriculum of migrant schools is also not good. Because of the lack of necessary facilities and high quality teachers, many schools can not provide the courses like English and Arts. Many schools try to follow the state curriculum but it is obvious that they cannot meet the state standards.

Due to the poor facilities, a lack of high quality teachers, many private migrant schools have been closed by the local governments abruptly. For example, as mentioned by Goodburn (2009), in Beijing, the government closed 50 migrant schools in 2001. Further, the Beijing government continued to close more private migrant schools in the following years, as reported by People's Daily (2011). In 2011, Beijing closed another 24 private migrant children schools, affecting 14,000 students. Most of these children had to find and attend other migrant schools and only a few children who have produced the necessary 5 certificates (parents' temporary 
residence permit, employment certificate, identification card, population planning certificate and social insurance certificate) were allowed to transfer to the public schools. In 2002 the district education department of Shanghai closed down several of its migrant children schools due to their poor quality (Wang \& Holland, 2011).

Overall, these private migrant schools are not recognized by the state and cannot offer their graduates state-recognized diplomas. The pedagogical standards in these schools are low and do not meet governmental requirements. So, these private migrant schools live in the margin and could be shut down at any time by the city government (Kwong, 2004; Mok, et.al, 2011; Chen \& Liang: 127, 2007).

Although many private migrant schools could not provide migrant children a stable education experience and equal education opportunities in the cities, the private migrant schools are the only way for many migrant children to attend schools in the receiving cities. It is because the tuition of those private migrant schools is much lower than the public schools, the migrant families only need to pay $300-450 \mathrm{RMB}$ per semester plus some schools charge separately for lunch, books and miscellaneous fees (Stanford Rural Education Action Program, 2014; Han \& Ding, 2004). However, the fees charged by the public schools could be as high as 4000 RMB to 6000 RMB per year (Chen \& Liang, 2007) only very few migrant children's families could afford it. The lower tuition fees of private migrant schools attract migrant parents sending their children to the private migrant schools. Thus, the private migrant schools also have become the only feasible option for the migrant children to receive compulsory education in the destination cities.

However, local governments are reluctant to accept migrant children in the public schools, because it will greatly increase their financial burden. Since 1985, China's government has 
implemented a comprehensive reform in the Chinese education system, introducing various measures to eliminate the excessive government control over schools and higher education institutions. This reform promotes the decentralization of different governmental institutions. Financial resources for the public schools have been diversified. The local governments have begun to support $78.8 \%$ of the school budget while the central government only supports 21.2\% (Mok, Wong, \& Yu 2011). Thus, without the sufficient support from the central government, for the cities with large numbers of the migrant children, limited public school funds in the urban areas could not cover all of the migrant children. The inclusion of migrant children into the education system will undoubtedly increase the financial burden on the local government. That is the main reason why local governments do not really want to include the rural migrant children into their public school system, even though the central government has enacted laws to support the education of migrant children in the urban areas. In the cities like Beijing and Shanghai, the governments are more likely to close those unqualified private schools rather than improve them. But in the Canton Province, the governments tend to support them.

Secondly, if the doors were fully opened, a large number of rural children, who are not the children of the migrant workers, will swarm into the city to take advantage of the policies for migrant education (Li, 2010) social order on large scale may be damaged.

\subsection{Laws or Regulations Relevant to the Schooling Issues of Migrant Children}

From the first appearance of migrant workers in the early 1980s to 2012, the population of migrant workers has been grown from 6 million to 250 million. However, the schooling issues of migrant children surfaced as late as mid-1990s, when the large number of young migrant workers had children or began to bring their children with them to the cities. In Shanghai, for 
example, the number of temporary migrants increased from 1.7 million in 1986 to 4.03 million in 2007 . The number of temporary workers' children was 340,000 in 2000 , comprising $12 \%$ of the total migrant population. In Beijing the numbers of migrant workers of 2007 was 3 million and, among this number, the number of migrant children was 397,493 (Chen \& Liang, 2007). By 2007, across the whole country, the number of migrant children had increased to 28 million. Of these 28 million migrant children, 22 million were left behind in their home villages while at least 6 million were in the cities (Chen \& Liang, 2007). And by the end of 2013, the number of migrant school-age children in the cities climbed to 12.77 million and this accounts for $9.3 \%$ of the total school-age children receiving compulsory education (Xinhua News Agency, 2014).

As appendix 2 indicate, The first compulsory education law was enacted in 1986. It stipulated that children or teenagers regardless of their race, sex and ethnicity who reach the age of 6 must receive 9 years of compulsory education (clause 5). The compulsory education is free and no school fee should be charged (clause10). The children should attend the nearest neighboring school to where their household is registered (clause 9). The compulsory education is guaranteed by the local government under the leadership of the central government (clause 8) (Law Library of China, 2014). However, this law failed to anticipate the schooling issues of the large number of the children of migrant workers who did not stay in their place of origin. When these rural migrant children come to the cities where their parent work, they are not under the jurisdiction of the local urban government, and as I mentioned beforehand, their Hukou (Household Registration Certificate) cannot guarantee their education rights in the urban areas.

The government did not realize the schooling problems of migrant children until mid1990s. In 1996, a Provisional Acts Regarding the Education of School-age Children of 
Floating Population (城镇流动人口中适龄儿童少年就学办法（试行）) was enacted by the central government. This provisional act discourages the rural migrant children from receiving compulsory education in the schools of the cities. It stipulates that state-run (public schools) only enroll children who hold local residence permits, which was nearly impossible for migrants to obtain at that time (Cheng \& Liang, 2007).

Two years later (1998), the central government issued another Temporary Regulation on the Schooling of the Migrant Children (流动儿童少年就学暂行办法). This regulation, for first time, stipulates that governments at both the migrant origin and destination have the responsibility of providing education to migrant children (Chen \& Liang, 2007). According to the clause 3 and 7 of this regulation, migrant children who do not have guardians in their place of origin can temporarily attend the public or private schools in their destination cities (SCAU, College of Public Management, 2011). This regulation requires the governments of destination cities to provide opportunities for migrant children to receive compulsory education. However, the biggest problem with this regulation is that it allows the destination urban public schools to charge Temporary Schooling Fees because the migrant children only "temporarily" attend the public schools in the destination cities. This fee could be as high as $600 \mathrm{RMB}$ per semester depending on the city and the quality of the local schools. In addition to the "Temporary Schooling Fees", this law does not prevent the local urban schools from charging other exorbitant fees such as sponsor fees. These sponsor fees could be as high as 2000 to 5000 RMB per semester (Cui, 2003). The local urban students enjoy free compulsory education and do not pay tuition and miscellaneous fees. However, migrant children from the rural areas who want to attend the public schools in the destination cities are often charged "Temporary Schooling Fees" and sponsor fees by the local urban schools. This is a form of discrimination 
against the migrant children. Migrant children come from the low-income families, they cannot afford the Temporary Schooling Fees and Sponsor fees (Cui, 2003). Thus, this regulation actually cannot guarantee the education rights of rural migrant children in the urban areas.

The local urban public schools and local governments also had no enthusiasm to implement this regulation because it required the local government to use their own education budget to support the education of migrant children. Thus, the migrant children cannot attend the public schools unless they pay unequal and expensive "Temporary School Fees" and "Sponsor Fees" required by the local urban schools.

In 2001, the central government issued the "Decision on the Improving and Reforming on the Basic Education (关于基础教育改革与发展的决定 2001)”, this decision stipulates that the migrant children should be placed under the jurisdiction of the government of the destination cities, should mainly attend local urban public schools, and that the local governments should take measures to guarantee the education rights of migrant children in the urban areas（两为主政策）(SCAU, 2011). This decision encouraged the local urban destination government to tackle the schooling issues of the rural migrant children.

In 2003, the Central Government issued the "Suggestions on Education of the Migrant Children (关于进一步做好进城务工就业农民子女义务教育工作的意见)”. These suggestions require the urban public schools to enroll as many migrant children as they could and established that local government has the obligation to education all children residing in the urban areas regardless of where their family's household registration certificates are registered (Wang L.H. \& Holland, T., 2011). These suggestions also required the local urban government to reduce or abolish the unequal fees charged to the migrant children who want to study in the local urban schools. It is important to note that it required that the rural migrant 
students and local urban children should be treated equally in terms of the fees that they are required to pay. Thus, for the poor migrant children, the local urban schools should reduce their school fees, provide free textbooks for them and provide assistance to help their schooling.

The key of implication is that the "2003 Suggestions on Education of the Migrant Children" requires the local urban destination government to allocate a special budget for the compulsory education of the rural migrant children in the cities exclusively, and that special budget should be a subset of the total local compulsory education budget (SCAU, 2011). This has caused substantial resistance on the city local governments to the implementation of this policy. Given the decentralized public finance system, the local urban governments have to use their own limited financial budget to support the education of the rural migrant children. At the same time this policy forbids the local governments to charge the migrant children exorbitant fees and asks them to charge migrant students and local urban students equally. Thus the implementation of this policy lacks financial support and the local urban governments have no enthusiasm to enact this policy. As mentioned by the Wang L.H. \& Holland, T. (2011), for many reasons the urban local governments have not implemented this provisional act to the full extent. Because central government has little enforcement power, this policy has been implemented only to the degree that the local government allows.

In 2006, a new "Compulsory Education Law" was enacted, this law stipulated that the migrant children can attend the public schools in other places than their Household Registration indicates. They can attend the local public schools in the cities where their parents work. In these cases the local urban government should provide the rural migrant children with the equal educational opportunity to the local urban students.

In the March 2006, the central government issued “The Central Government's Suggestions 
on Solving the Multiple Issues of Migrant Workers(国务院关于解决农民工问题的若干意

见)”, among these suggestions, clause 21 states that the destination urban government should shoulder the responsibility to educate migrant children in the urban area. It stipulates that the local urban government should enroll migrant children in the local public school system and that their education budget should also provide for the compulsory education of rural migrant students in the cities. The urban public schools should treat migrant students equally and Temporary Schooling Fee and other fees should be totally forbidden (Chinese Government, 2006).

These suggestions represented a breakthrough in guaranteeing the equal education opportunities for rural migrant students and local urban students. This is because these suggestions also stipulate that governmental funds to public schools should be based on the real numbers of students in the schools, not based on the number of students who have local Household Registration. This is to say, as long as the local urban public schools take in rural migrant students regardless of their Household Registration status, the local public schools can get the same amount of the education fund from the local governments as when they enroll the same number of the local urban students.

In 2010, the Chinese government made a National Long-term Plan for Education Reform and Development (国家中长期教育改革和发展规划纲要 2010-2020), and solving the education issues of the migrant children has also been incorporated in this plan. This plan not only consolidates the basic policy on the migrant children: "the destination urban government should take a main responsibilities on the provision of education for the migrant children, and the migrant children should mainly attend the urban public schools in their destination cities (两为主政策)", but also at the same time, required the local urban government to work out 
plans for the migrant children to sit for the High School Entrance Exam and College Entrance Exam in their destination cities (Chinese Government, 2010).

From the laws and regulations above, we can see that the central government wants the local governments to regard the migrant children as local students, and help migrant children in solving their education problems and improved social services for the migrant workers' families. However, due to China's decentralized administrative and fiscal system, the Chinese central government has limited power to enforce the laws in the local level. The local governments only implement this law at their own will (Wang \& Holland, 2011; Mok, Yu C. W. and Yu G., 2011). So even through the central government has vowed to settle the schooling problem of migrant children in the cities, the truth is that at the local level, many rural migrant children still cannot attend urban public schools. In many cities, the schooling rate of migrant children still ranges from $65 \%$ to $85 \%$ and that means between $15 \%$ and $35 \%$ of the rural migrant children in the cities still cannot attend public schools. As a result they may end up attending unqualified underground migrant schools.

The changes of the education policies for the migrant children in the past two decades illustrate the fact that the Chinese government has slowly realized the importance of the education equality for the vulnerable migrant children. The increasing numbers of the rural migrant workers and migrant students arriving in the cities made Chinese government at different levels realize the urgency to address the needs of migrant children receiving public education and equal treatments in their destination cities. This may be a force that drives changes of the education policy for the migrant children in the cities.

\subsection{Decentralized Educational Administrative and Fiscal System}

Since the late 1970s, in order to coordinate its "economic reform and open up", as well as 
transform a centralized planned economy into a market-oriented economy, the Chinese government also began to reform its centralized administrative and fiscal system by giving certain autonomy to the local governments. As mentioned by the Mok, et.al. (2011), since the mid-1980s the Chinese government began to streamline administration and devolve power to units at lower levels ( to the provincial, municipal and county levels), and at the same time, the central government also has adopted a policy of decentralization to encourage governments at lower levels to diversify financial sources and increase the education finance provision. That is to say, local urban or county governments have to share a larger percentage of education budget than they did before, while the central government tends to shoulder a smaller percentage of the overall education budget. According to the National Bureau of Statistics of China (2009), in 2008 the central government only paid 5.5\% (49.1 billion RMB) of whole the budget while the local governments had to pay $94.5 \%$ ( 851.858 billion RMB) of the whole budget.

In order to increase the local government shares on the budget of compulsory education, the central government in 1986 allowed the local governments to collect a $2 \%$ "additional education-tax" from the individuals, companies, and institutions on top of their product tax, added value tax and business tax (Liu Y. J., 1992, p. 99). In 2005, the additional education-tax rate has been increased to 3\% (Law Library, 2005).

What the central government wanted to do is to increase the enthusiasm and initiative of the local educational institutions to develop the local basic education. However, it did not anticipate potential negative consequences to the poor rural areas of China as well as to the rural migrant children in the cities.

For example, as mentioned by the People's Daily (2005), the decentralized fiscal and 
administrative system in education has caused a severe unbalanced development of rural and urban education. The poor rural areas do not have sufficient finances to improve its basic education without support from the central government. They have insufficient funds to improve the education facilities and to pay teachers' salaries. As the People's Daily (2005) mentioned that in 2002, China has put 580 billion RMB investment on the education. Yet, the rural areas only contribute $23 \%$ of the total investment while the population of the rural areas constitute $60 \%$ of the total population of China. The poor rural areas do not have sufficient high quality public schools. The facilities, teachers and curriculum of the urban public schools are much better than the rural area. That is one important reason that rural migrant children prefer to attend public schools in the cities rather than in their poor rural hometown and villages.

The decentralized administrative and fiscal system in education also influences the enrollment of the rural migrant children in the cities. The Compulsory Education Law requires the local city and county governments use their own budget to solve the compulsory education issues of their local children. Technically the migrant children, who do not have Household Registration in their destination cities, are not under the jurisdiction of the local urban government. Instead, the migrant children belong to their original villages and the governments of their rural hometowns. Before "The Suggestions on Solving the Multiple Issues of Migrant Workers" was enacted in 2006, the compulsory education for the migrant children was not included in the financial budgets of the local urban governments. There is still no special financial support from the local urban governments for the urban public schools which enroll migrant children. As a result, in many cities, the migrant children have to pay a "Temporary Schooling fee" and other fees to study in the local urban public schools. After 2006, the cities 
such as Ningbo, Wuhan created a special fund to encourage public schools to accept migrant children ( $\mathrm{Li}, 2010)$. For example, as mentioned by $\mathrm{Li}$ (2010), Wuhan city government provides 3 million RMB to public schools accepting migrant students, and Ningbo city government increased its special education fund to 6 million to subsidize public schools accepting migrant children. The Wuhan city government also abolished unequal fees charged to the migrant students. In the cases of Wuhan, Ningbo, Nanjing and Hangzhou, these cities do not have large numbers of migrant children (100,000 to 200,000$)$, so they could have sufficient governmental funds to absorb the rural migrant children into the public school system. So in these cities $60 \%$ to $80 \%$ of the migrant children are able to attend the public schools.

Not all of the cities in China are able to absorb rural migrant children into the public school system, in the cities of Pearl River Delta of Canton Province such as Shenzhen and Guangzhou, there are too many migrant children (2.44 million non-resident migrant students in Canton Province in 2010). In 2010, only 170,000 migrant children managed to attend the urban public schools in the city of Guangzhou, and this number constitutes less than $40 \%$ of the total migrant children in the city, although $60 \%$ of the school-age children in Guangzhou city were migrant children. Shenzhen public schools only enroll $41.3 \%$ of the non-local students (Li, 2010; Yuan, 2010). The numbers of migrant children far exceed the local school-age children. As a result, the existing public school systems and fiscal budgets of these cities do not have sufficient capacity for the large numbers of migrant children. So, they have to rely on the private migrant schools to help them solve the education problem of migrant children.

As can be seen, relying only on the local urban governmental budget cannot fully solve schooling problem of migrant children. Different parties should be involved in the provision of the education for the migrant children. The central government, provincial governments, 
together with destination urban governments, original rural governments, urban education bureaus, urban public schools and private migrant schools need to be coordinated well to solve the education issues of the migrant children.

As mentioned by the Tian \& Wu (2008), the central government should provide special funds to financially support the education of the migrant children in the local urban areas. Actually in 2009, the central government forwarded a 2 billion RMB special funds to the urban public schools which enrolled migrant students, in order to offset the increase of the public education expense incurred by the enrollment of migrant children, as well as to improve the schools' facilities. In 2011, the central government awarded 100 million RMB to Anhui Province praising its efforts to improve the education quality for the migrant children (Xinhua News Agency, 2009). This 100 million RMB award was used to support the schools which enroll migrant students by improving their facilities, and providing them funds to purchase books, information and communication facilities.

In addition, many provincial level governments also began to provide special funds to help migrant children. For example, in 2013, the government of Jiangsu Province forwarded 30 million RMB to help public and private migrant schools in the Jiangsu Province improve their facilities and rebuild their public-use funds. And from 2006, the Jiangsu Province begin to provide special funds to improve the education of migrant children (Xian Dai Kuai Bao, 2013). In addition, from 2010, the government of Guangxi Province provided special funds to exempt migrant students from paying temporary schooling fees and miscellaneous fees in the public schools (Nan Guo Zao Bao, 2012).

Tian \& Wu (2008) and Mok, et.al. (2011) suggested that the governments issue education vouchers to migrant children. The voucher is a special certificate, and with this voucher, the 
public schools that migrant children attend could get relevant education funds from central government, the migrant children's original government, and destination government. The money can follow the migrant children wherever they go. However, for many reasons this suggestion has not yet been adopted by the central government.

The decentralized educational administrative, fiscal system and Hukou in China makes it difficult for the migrant children to receive compulsory education in the cities. Under this decentralized administrative and fiscal system, the biggest challenge is how different levels of governments could coordinate efficiently to support the education of migrant children. The decentralization of the administrative and fiscal system creates tensions between central and local governments. As mentioned by Mok, Yu, C. W. and Yu, G. (2011), the central government has repeatedly urged the local governments to shoulder more responsibilities on the local issues (such as providing education for the migrant children). However, the local governments are reluctant to provide migrant children education because it could undoubtedly increase the financial burden of the local governments, decrease the quality of public services for the local residents, and may hinder local economic development. However, consider the fact that the migrant parents work in the local areas, and like the native urban dwellers, they also pay taxes and contribute to the local economy, so why should not their children receive public services (attend the public schools) in the local area? So, the excuses of the local government for not providing education to the migrant children seem overwrought.

It can be argued that providing education to the migrant children in the cities is more important than the short-term economic growth of the cities. It is an important aspect of social harmony and fairness. The leaders of the cities should realize the importance of social harmony and fairness. 
To achieve this objective, the provincial and urban governments should not have any selfishness, and should treat local students and migrant students from other places equally. The governments' funds to each public school should be based on the actual number of the students in the schools and the rural migrant students should be enrolled like the local urban students. The central government should generously offer financial support to the cities which really have difficulties in providing education to the migrant children. The 2 billion RMB budget from central government to improve the migrant children education may not be enough considering the huge number of the migrant children in China. Of course, at the same time the central government must make sure all of its budget is properly used and not wasted.

To overcome this problem, different levels of the governments and local schools should work together to provide financial support for the migrant children to attend public schools in the cities.

\subsection{Different Cities have Developed Different Solutions to the Education Issues of the Migrant Children}

Because of the decentralized education and governmental administrative system of China, the central government has given much freedom for the governments of different cities to work out their individual solutions for the education issues of the rural migrant children. Based on their own situations, different cities have work out their own plans to address the issues.

As I mentioned beforehand, the governments of Wuhan, Tianjin, Hangzhou, Nanjing, Shaoxing, Jiaxing, Ningbo, and Suzhou try to incorporate the migrant children into their public education system as much as possible. Yet the city governments in Guangdong Province have to rely on the private migrant schools to solve the education issues of the rural migrant children.

In the capital Beijing, in 2009, there were about 3 million migrant workers and 418 
thousand migrant children. $67 \%$ of these migrant children attended public schools, while the rest of the migrant children have to attend the low-quality private migrant schools $(\mathrm{Li}, 2010$; Yuan, 2010). Compared with Guangdong Province, Beijing has done a relatively better job in ensuring the majority of the migrant children get into its urban public schools. However, at the same time, in 2009, there were still about 200 private migrant schools in Beijing, and only about 60 private migrant schools had obtained a license from the government. The Beijing urban government also provided a small amount of funds to help those licensed private migrant schools (Yuan, 2010). The Beijing government choose to close many of the unlicensed lowquality private migrant schools.

Like Beijing, in 2007 Shanghai city (Shanghai has 6.6 million floating population in 2007) has also incorporated large numbers of the migrant children $(221,000)$ into its urban education system and this number accounted for $58.2 \%$ of the total number of migrant children (Li, 2010, pp.181). In 2008, nearly 65\% of the migrant children in Shanghai attended public schools (Yuan, 2010). The urban government of Shanghai also tried to bring underground private migrant school under private educational management. For those low-quality private migrant schools, in order to improve and update their facilities, the Shanghai urban government provided a 500,000 RMB fund to each private migrant school. In order to get the fund, each private migrant school has to pass a third-party educational assessment and then sign a contract with district or county-level governments (Li, 2010, pp.183). In 2007 and 2008, 116 private migrant schools were transformed into the management of the private education. Like Wuhan, the migrant children in the private schools of Shanghai also do not need to pay for the tuition and textbooks. The urban government also provided $1900 \mathrm{RMB}$ per person per year for the private migrant school to enroll migrant students in 2008 , and the subsidy was 
increased to $3000 \mathrm{RMB}$ in 2009 (Li, 2010, pp.183). The Shanghai government also shut down the private migrant schools which do not meet the private school standard. 


\section{CHAPETER 3: ADOPTING CULTURALLY RESPONSIVE EDUCATION (CRE) IN URBAN PUBLIC AND PRIVATE SCHOOLS FOR MIGRANT CHILDREN OF CHINA}

The Vice Education Minister of China, Du K.W. (2014), has mentioned that in 2013 there were 12.77 million migrant children nationwide. $80.4 \%$ of the migrant students attended public schools in their destination cities. Public education funds from the local urban governments had been allocated to support the compulsory education for the migrant students in both urban public schools and some private migrant schools in Shanghai and Zhejiang Province. The public education funds from the national and local governments have covered $83.5 \%$ of the migrant children for their education in the destination cities.

More and more migrant students have been enrolled by the urban public schools and private migrant schools. A new question has come to the surface: how to best educate those migrant students in the public and private schools?

The rural migrant students and local urban students are different in their cultural and social backgrounds. When the migrant students come to the desegregated urban public schools or private migrant schools in the cities, teachers should notice the differences and use different education strategies. Schools should improve the education quality for the migrant children, and different level of governments should provide more financial and material support for the education institutions accepting migrant children. Most importantly, a CRE should be adopted by the schools in order to educate the migrant students effectively.

Cultural deeply influences the way that a person learns, and learning is a cultural and social process. Learning and development can be seen as the processes of encountering, 
engaging and negotiating the cultural elements around students (Taylor, 2010). For the cultural majority group, this process is natural and easy, because the culture they encounter is their native culture and they are quite familiar with it. However, for the students from a cultural minority group this process can be extremely difficult.

A culturally responsive education should be implemented to address the needs of migrant students in China, and could potentially solve their schooling problems. As more and more public schools in the cities began to take in rural migrant students, urban public schools should address the special needs of these children and solve their unique problems.

According to Taylor (2010), there are 3 components of the cultural responsive education: institutional, personal and instructional.

(1)Institutional: Changes must happen in the school and educational policy, school organization in order to promote equality of education.

(2)Personal: When the teachers teach in the classroom and communicate with the students of different cultural background, they should realize the differences in students' cultural backgrounds. Teachers should never discriminate against the students of different culture, should never have negative feelings toward any culture, but instead learn to appreciate the unique cultures of different students.

(3) Instructional: Different strategies and teaching methods should be used to teach students of different social-economic backgrounds, different races, and different linguistic group. Wise teachers should also make use of students' native culture as an important resource to teach those students, to open their horizons, and improve their academic achievement. As Mentioned by Gay (2000), teachers should use the students' cultural knowledge, prior experiences and performance styles to make learning more 
appropriate and effective for them.

First, changes must happen in the school, education policy and school organization. In order to make sure all of the rural migrant students are able to attend the public schools, reform in the national school policy, and school organization, especially reform of school finance should be implemented. Currently, China has adopted a fiscal decentralization system. The central government provides less than $6 \%$ of the public school funding, the rest of the funds to operate public schools are provided by the local provincial and municipal government (Mok et al., 2011). Sometimes, the local urban governments may not be able to collect sufficient public education funds from the " $2 \%$ Additional Education Tax" from the individuals, companies and institutions to support the schooling of all the children residing in the local areas. As in the case of Guangdong Province, the numbers of the migrant children were far exceeding the numbers of the local children. The local urban governments may consider the possibilities of increasing education tax to absorb more migrant children into their public school education system. In the US, the local property taxes pay for a significant portion of public education expenses, as mentioned by Berry (2011), local revenue typically pays sound $25 \%-55 \%$ of expenses, while state revenue contributes $33 \%-88.5 \%$ of expenses, the federal funding only constitutes $10 \%$ of the public education funds that a school district receives. China is different from the US, because China now does not collect property taxes. Although "The Additional Education Tax" rate has been increased to $3 \%$ from 2005 , local urban governments may still not able to collect sufficient public education funds. Thus, if the local urban governments of China began to collect property taxes from the individuals, companies and institutions, the local urban governments would be able to increase their governmental revenue, so that more public education funds would be available to address the education issues of the migrant children in 
the urban areas.

Although the Compulsory Education Law of 2006 required the local governments to equally provide free nine-years of compulsory education to the rural migrant children in the cities, the local governments do not want to implement this policy. Because the central government failed to provide sufficient funds to the local cities for the schooling for the rural migrant students in the cities. The local urban governments have to use their own funds to provide compulsory education for these children. But not every city in China are capable of providing sufficient funds and supports for improving the education quality and schools facilities of the private migrant schools located in those cities. For example, as I mentioned beforehand, Beijing government is in general hostile to the private migrant schools and a lot of private schools were closed by the local urban governments abruptly (Kwong, 2004). The reasons given were that these schools did not meet the government's safety standards and school facilities were very poor. Instead of providing necessary financial and material support, the local governments closed these school abruptly making thousands of migrant students ceased to receiving schooling over a period of time.

In order to implement CRE, making education quality equal between migrant students and local urban students, governments should support all of the private migrant schools. These private migrant children schools need big improvements in their facilities, as well as the quality of their teaching staffs. To achieve this objective, these private schools need considerable governmental funds. Only relying on the funds collected from the students' tuitions cannot solve the problem. They also need support from the local and central government, NGOs and personal donations. In China, from 1985, the government begun to privatize its education institutions (Mok et al, 2011), and private schools have been allowed 
since then. However, many private education institutions, like the private migrant schools, are actually short of the funds to operate. Individuals, different organizations, social groups and charities should be organized to provide funds to support the private migrant schools. Up until now, the individual material donation to the private migrant schools has been far from sufficient. People are more likely to focus on the schooling issues of the students in the rural and mountain areas, since this issue has been broadcasted by the public media for many years. Yet, for many reasons, schooling issues of the rural migrant students in the urban areas had been neglected by the people until recent years.

The knowledge foundation and academic ability of some migrant students tends to be weaker than the same grade urban students. So from the perspective of instruction of the CRE, the urban public schools should take good care of those migrant students, they should provide repeated individual consultations to migrant students who are in trouble with their studies. Since the parents of migrant children are much busier with their work than the local urban parents and they do not have time to help their children with homework, the teachers in the public school should also try to help them do homework and solve the problems assigned to them. This is difficult, especially when the teachers have quite a lot of other work to do. I recommend volunteers help migrant children do homework and solve their problems.

However, the rural migrant children also have advantages compared with the urban children. The migrant children and urban children are different in their knowledge structure. The migrant children may have more knowledge about countryside and nature. They may also more likely to know about the hardships of daily life and can endure to these difficulties. While the urban children are more likely to be alienated from the nature and countryside. They may also behave like flowers in a greenhouse susceptible to frustrations from their daily life and 
study since they were grown up in a prestigious environment and they are not likely to worry about their daily life. Generally speaking, rural migrant children are more hardworking than urban students in their school coursework. Thus migrant children are more likely to thrive in the competitive environment in the urban public schools. To implement CRE, the teachers should improve the self-esteem of the migrant children, and give more praises to their achievements at school.

The other problems that the migrant children will face when they attend public school include discriminations, school bullying, emotional stress and psychological problems (Lu \& Zhou, 2013). It has been reported that some rural migrant children were discriminated against the local urban students at urban public school. In China, there are very big cultural differences between the rural people and urban people in terms of their lifestyle, knowledge structures, characters, accents and ways of talking. When the rural migrant students go to the urban schools, they are very unlikely to be accepted by the urban classmates and school bullying is very likely. Thus, the migrant students will feel very lonely and depressed in the urban schools (Lu \& Zhou, 2013).

So, in order to implement a culturally responsive education, public schools should pay special attention to the mental and psychological health and wellbeing of migrant students. They should provide the frequent consultations with the migrant students in order to know about and help with their emotional and psychological problems.

One of the controversial measures in the urban public schools is arranging migrant children into special classes separating them from normal urban students. This has hurt the feelings of the migrant children (Kunming Daily Newspaper, 2014). In order to implement the cultural responsive education, the public schools should include migrant students in normal 
classes together with urban students. This measure could provide them with more opportunities to make friends with the local urban students and could reduce their loneliness in their classes, and make migrant children better integrated in urban society.

The characteristics of culturally responsive teaching include a positive parent and family involvement in children's education, teachers' high expectations of the students, learning and instruction within the context of culture, student-centered instruction, reshaping the curriculum and teacher as facilitator (Teaching Diverse Learners Program, Brown University, 2014). According to these characteristics of culturally responsive teaching, public schools should do the following jobs. First, the parents of the migrant children must be positively involved in their children's education. To achieve this objective, the teachers should communicate with the parents of migrant students frequently. As suggested by Nieto (1996) and Brown University (2014), teachers can have dialogues with the parents of the migrant children formally and informally in order to learn about the family background of the each migrant student. Second, teachers of migrant students should have high expectations of every migrant student for their school work, even if some of them temporarily have poor foundations in their knowledge and school work. Third, teachers should pay special attention to the cultural characteristics of the migrant students, because their unique family cultures could influence their habits of learning. The migrant students, especially females, tend to be matured earlier mentally and behaviorally than the local urban students, and they also tend to be more independent and self-regulatory in their daily life and study than the normal urban students. Since the parents of the migrant children are more likely to be busy with their work than the local urban parents, migrant children have to do more housework by themselves at home such as taking care of their younger brothers and sisters. With long-term practice, they tend to do very well in both of their 
study and housework.

However, at the same time, the migrant children are also likely to be the victims of poor family education. Mi (2008) mentioned that migrant children tend to suffer from various family education problems. One of the problems is migrant parents' low expectations towards the outcomes of their children's education. This problem is caused by the education barriers that migrant children suffer in the urban area. The migrant children have to pay a lot of money in order to attend urban public schools, and many migrant families cannot afford these charges. So the migrant parents have to lower their expectation of the outcomes of their children's education.

Through interviewing 20 migrant children's families in Chengdu, Mi (2008) also found that the parents of migrant children were likely to use both authoritarian and lassies faire parenting style with their children. For one thing, many parents of migrant children often force their children to do this and that, and the migrant children often suffer from family abuse. Being spanked and scolded by their parents is very common for many migrant children. For another thing, every day many migrant parents have to spend long hours working outside the home in order to make money for the families and they have no time to take care of their children. The migrant parents may have little time to support and take care of their children emotionally and spiritually. It seems that that many migrant children are "abandoned" by their parents and the necessary communication between parents and migrant children are restricted.

Similarly, Zhu (2014) found that, there were 41.9 thousand migrant students in Beijing in 2012. Many parents of these migrant children do not like to communicate with the schools that their children attend. These parents are likely to believe that educating the children is solely the schools' responsibility. Many migrant parents are also likely to neglect the character education 
of their children and fail to cultivate good virtues in their children. Some migrant children have developed bad behaviors or even commit crimes.

In order to implement $\mathrm{CRE}$, teachers of migrant students should provide more consultation for those migrant students who suffer from family abuses or been neglected by their parents. At the same time the school should also provide necessary guidance to the parents of migrant children, requesting them to educate their children in appropriate ways at home. More family-school meetings should be conducted by the schools in order to teach migrant parents how to educate their children in right ways. The teachers should visit the homes of migrant children regularly in order to know about the migrant children's family culture and provide necessary assistance to the migrant parents.

The schools in the urban areas should also employ more teaching staffs from rural areas. The rural teachers were grown up in the rural areas, they tend to know about the situations of rural areas, characteristics of the rural children and their families more than urban teachers do. Rural teachers know how to communicate with rural migrant children effectively, and they are likely to adopt teaching strategies that are most suitable to the rural migrant children. At the same time, the rural migrant children and their families are more willing to communicate with the teachers who have the same social and cultural background like them. Thus, employing teaching staffs from the rural areas could diminish the distance between migrant children's families and urban public schools, and could eliminate potential conflicts.

In order to promote the mutual understanding between the urban students and rural migrant students in the urban public schools, more school and classroom activities should be held. These activities should encourage migrant students and urban students to work together. The rural migrant students should be mixed with urban students in classroom activities. In the 
weekly class meeting, the migrant children should be encouraged to share their life experience in the rural areas with the urban students. The urban children should also be encouraged to talk about their life in the city.

When teachers teach in the classroom, they should incorporate the cultural knowledge and past experience of migrant children, in order to make learning more appropriate and effective (Gay, 2000). For example, when a geography teacher teaches the concepts of weather and climate change to the rural migrant children, he can use some slangs pervasive in the country area and farmer almanac that the migrant children are supposed to be very familiar with as the teaching material. By doing so, the teacher is able to connect classroom knowledge to the experience that migrant students are familiar with, and make could scientific knowledge meaningful. 


\section{CHAPTER 4: CONCLUSION}

This thesis discussed the education problems of the rural migrant children in the cities. Migrant workers are a vulnerable population in the cities. Migrant workers suffer from the institutional and systemic discriminations in the cities (Xiong \& Yang, 2012) and their children's rights to receive high quality education in the cities have been violated.

As many as $20 \%$ of the migrant children still have to attend low-quality private migrant schools, and attending these private migrant schools in the cities are still an important way for the migrant children to receive education in the urban areas. So, in order to help those private migrant schools, the government should legalize all of the private migrant schools. The illegal migrant schools need recognition and approval from the local government. Without the permission of the government, they are unprotected by the state law.

Second, governments of all levels should provide sufficient funds to renovate the school facilities, improve the safety condition of the classroom, to pay for teachers' salaries, teacher's training, and maintain the operation of the schools. The central government should shoulder more responsibilities for the finance of migrant schools by providing special funds.

Third, the government should improve the quality of the teaching staff in the migrant schools. Currently, the teachers in the migrant schools are extremely low in quality, they are nether professional nor experienced. Many of the teachers in the migrant school are part-time teachers. Most of the teachers were not well educated. The majority of them have not received college education or professional training and they have not obtained teacher's certificates. Many teachers were only slightly higher in their academic skills and education attainment than 
their students. The migrant school should recruit teachers from the colleges and universities, and in-service teachers should receive frequent professional training to upgrade their knowledge insuring they can use the latest methods to teach their students.

Currently, the most effective way to educate rural migrant children in the urban areas is incorporating them into public schools and mixing them with local urban children. Now $80.5 \%$ of the migrant students attend public schools in the cities. However, simply placing migrant children together with the local urban students is far from enough. A culturally responsive education should be implemented to improve the quality of education for the migrant students. Since the migrant students in the urban public schools tend to face peer discriminations, school bullying, emotional stress and psychological problems in the public schools, the teachers should pay attention to the wellbeing and psychological and emotional health of the migrant students in the public schools. At the same time, many migrant children are also the victims of the parent abuse or neglect by their parents. The schools should communicate with the parents of the migrant children frequently. By holding more school-parent meetings, the schools could educate the parents of migrant children how to teach their children appropriately and shoulder their responsibilities for educating their children.

According to the Classic Assimilation Model, when the immigrant children try to integrate into the mainstream society they tend to have a lot of deficiencies compared with the children of the mainstream society. These deficiencies are mainly embodied in the aspects of experiences and beliefs, cultural communication patterns, languages and educational traditions of the immigrant children (Rong \& Preissle, 2009, p. 11-17). These deficiencies will hinder the immigrant children to integrate into the mainstream society of their destination countries, to be successful academically at school, and achieve upward mobility in the destination society. 
Although the Classic Assimilation Model cannot be fully used to analyze the situation of the internal migrant children in China, migrant children do have some disadvantages at schools compared with urban students. For example, the knowledge foundation and academic abilities of the migrant children who transfer to the public schools tend to be weaker than the same grade local urban students. And due to a different family educational tradition, some migrant parents do not like to help their children with their school coursework. To address these problems, teachers should provide frequent individual consultations to those migrant students to help them catch up with the local urban children in their school course work, provide remedies for their bad study habits, and adjust their potential behavioral problems. Due to the family and social environment of the rural migrant children, they tend to have a narrower sphere of knowledge of the world and weaker literacy skills than the local urban students. Thus the teachers should broaden the horizon of migrant children by introducing more interesting learning material, improve character education, and cultivate the minds of the students. The rural children usually have lower self-esteem and confidence in the new urban environment. Thus the teachers should boost their confidence about themselves. By more frequently praising their achievements at school. This could build up their self-esteem little by little.

At the same time, the migrant students do have advantages compared with the urban children. According to the Pluralistic Additive Model, immigrants' optimism, work ethic, and cultural and linguistic resources could actually enrich the cultural heritage of their destination places (Rong \& Preissle, 2009, p. 11-17). The migrant workers are hardworking, smart, brave, and could endure to different difficulties and frustration in their life. Like their parents, the children of the migrant workers are also hardworking, smart and honest. These characteristics could not only help the migrant children to be successful at school, but also could improve the 
school culture of urban schools. Thus, incorporating migrant children into urban public schools is very necessary.

However, Xiong \& Yang (2012) mentioned that it is far from enough for the urban governments to open the gate of the urban public schools to the migrant students, as the urban public schools have limited effects on integrating migrant students into the urban society. The current education system in China has failed to provide migrant children sufficient opportunities to thrive in the cities and to have upward mobility in the urban society because the urban society repel the families of the migrant workers systemically and institutionally. Xiong and Yang (2012) also believe that since the discriminations towards the rural migrant workers still exist in the areas of employments, social welfare, and higher education, simply providing the rural migrant children with opportunities to receive urban compulsory education will be useless.

The families of the migrant children face many challenges in the cities, not only compulsory education opportunities but also the opportunity to receive higher education and many other areas. The migrant children cannot sit for the College Entrance Exam in their destination cities. They have to go back to their hometown to take the exam. They need to get a much higher scores on the exam than urban students in order to be admitted by the same universities. The systematic and institutional discrimination towards migrant workers and their families in the cities cannot be easily changed, and may need a long term process. The disparities between the urban and rural areas of China has been existed for decades driving poor rural farmers leave their rural hometowns and work in more prosperous cities in order to seek for a better material life. But the discriminations that the rural migrants face in their destination cities has awakened them to the big gaps between their dreams and the realities in 
the cities.

The poor plight of the rural migrant workers and their children in the cities have made me realize that migrant workers have little social power to change their education situations in the destination cities. Most of the successful reforms regarding the schooling issues of the migrant children is through top-down efforts. For example, the central and local governments order the local urban public schools to execute the relevant policies to guarantee the education rights of the migrant children in the cities. The migrant workers' own efforts to improve the education status of their children, such as establishing their own private migrant schools for their children, are not successful and have met many obstacles. The local urban governments are not happy that private migrant schools are beyond their control, so they close most of the private migrant schools. By strictly restricting the opportunities of the migrant children from sitting for the college entrance exam in the destination cities, the local urban governments actually want to discourage the migrant children from attending the public schools in the cities and further to discourage migration itself.

Migrant workers are the most vulnerable group in the cities, and this vulnerability is caused by the social power structure of China. The governmental policies could either reduce or eliminate this vulnerability, but could not really remove all of the discrimination against the vulnerable groups of China. As in the case of the migrant children in China, although now $80 \%$ of the rural migrant children attended the urban public schools, only 4444 rural migrant students nationwide managed to sit for the college entrance exam in their destination cities in 2013. Without the change of the social power structure, even if in the future all of the rural migrant students were able to attend the public schools and sit for the college entrance exam in their destination cities, there would still be much discriminations against migrant children and 
migrant workers.

Xiong and Yang (2012) and Bourdieu (1998) mentioned that schools exist in a wide political-economic-social space, and the education is subordinate to the arrangements of policy and social power. Education may not be able to eliminate the social inequalities created by social power and economy. However, individuals, receiving a good education could change their fate, potentially empowering them to have a better life in the future, especially for the venerable groups. Dewey (1916, pp.30) mentioned that:

Growth is the characteristic of life, education is all one with growing. The criterion of the value of school education is the extent in which it creates a desire for continued growth and supplies means for making the desire effective in fact.

The purpose of education is to promote the growth of the individuals. Our society should provide better education opportunities for vulnerable groups in order to enable them to thrive and develop in our society. However, currently in China, the school neither provide good opportunities for the migrant children and their families to "grow" in their destination cities nor creates a desire and supplies meant for their continued "growth". As Dewey explained: In directing the activities of the young, society determines its own future in determining that of the young, the young at a given time will at some late date compose the society of that period, the latter's nature will largely turn upon the direction of children's activities were given at early period. This cumulative movement of action toward a later result is what is meant by growth. (Dewey, 1916, pp.25)

The migrant children are the younger generation and they will compose our society in the future. "The nature of the society will largely turn upon the directions of children's activities". If we expel the rural migrant children from the urban education system and place them in a 
poor and unequal education condition, it will very likely aggregate their resentments and hatred towards the urban people and society. The rural migrants may, finally, even develop criminated activities toward urban people. And hatred and resentments between the rural and urban people may further aggregate the urban-rural disparities. The widening disparities between the rural and urban areas may finally deteriorate social integration and harmony. This is what we do not want to see.

By incorporating migrant children into the urban education system and reducing their difficulties in taking the college entrance exam, we could ameliorate the negative effects of institutional and systematic discriminations toward the migrant children and their families. It should reduce migrant workers' negative feelings towards the urban people and society, and promote social harmony and integration.

Education without discrimination and distinction (有教无类) is also the main thought of the Confucius. However, it is very sad and disappointing to see that the Chinese society now offends this creed, because education by nature is subordinate to the social power and policies. The current public education system in China has reinforced the social inequality because it is served for the interests of the dominant urban classes. The interests of the rural migrant children has been compromised. Without thorough reforms, this system will continually reproduce inequalities.

From the first appearance of the migrant children in 1995s till now, China has spent almost 20 years trying to solve the education issues of migrant children. Now, there are still about $20 \%$ migrant children cannot attend high quality urban public schools. Why has China taken so much period of time to address this problem? The inefficient decentralized, education administrative and fiscal system is one important reason. Huge population and economic 
disparities of different regions is another reason, and however, there is one important reason.

China is still a bureaucratic and autocratic country, social power is held by a few people. The rural migrant workers class has little power to change their inferior social status in the cities.

China now is undergoing a process of profound economic and social transformations, its public policies may still be incomplete in many ways to address the new emerging issues and protect the legal rights of its citizens. The education experience of rural migrant children in the cities proves that China still has a long way to go to achieve equality in education.

\subsection{Suggestions for the Future Researchers}

Currently, most of the cities have begun to address the schooling issues of rural migrant children. Many migrant children (more than $80 \%$ ) are able to attend the public primary and secondary schools in their destination cities. So the education status of the migrant children has been improved in recent years with the joint efforts of the central government and the local urban governmental authorities.

However, after the migrant children were graduated from the secondary schools, they should continue to be able to attend high schools, colleges or universities in their destination cities. However, most migrant children still cannot attend high schools and sit for the College Entrance Exam in their destination cities. Future studies of the education issues of migrant children in China should pay more attention to migrant children attending urban public high schools, as well as their rights of sitting for the College Entrance Exam in their destination cities.

The migrant children in Beijing and Shanghai still do not enjoy the equal right of siting for the College Entrance Exam in their destination cities. In most of the cities, public high schools are not open for many rural migrant children, because high school is not compulsory 
education in China. In the 2014 annual American Educational Research Association conference, Yiu (2014) from the Stanford University mentioned that in Shanghai, many rural migrant children whose parents failed to meet certain standard, not only could not attend high school in Shanghai, but also they also have to go back to their rural hometown to sit for the College Entrance Exam. Thus, the rural migrant who takes the exam in their rural hometown will need to get a much higher scores in their College Entrance Exam than the urban local students in the Shanghai in order to be enrolled by the same tier of the universities.

The rural migrant students cannot attend the high schools in their destination cities, they cannot sit for the College Examination and enjoy an equal opportunity to be enrolled by the colleges and universities like the local urban students. These points are what the future studies on the migrant children education in China should focus on. 


\section{APPENDIX 1}

TYPES OF SCHOOLS THAT MIGRANT CHILDREN COULD ATTEND IN THEIR DESTINATION CITIES BEFORE 2006

\begin{tabular}{|c|c|c|}
\hline $\begin{array}{l}\text { School } \\
\text { types }\end{array}$ & Advantages & Disadvantages \\
\hline $\begin{array}{l}\text { Public } \\
\text { Schools }\end{array}$ & $\begin{array}{l}\text { 1. The migrant students are } \\
\text { mixed with the local urban } \\
\text { students (equal education } \\
\text { opportunities). } \\
\text { 2. Facilities and curriculum meet } \\
\text { national standards. } \\
\text { 3. Teachers are professional and } \\
\text { experienced. }\end{array}$ & $\begin{array}{l}\text { 1. Charge temporary schooling fee, } \\
\text { sponsor fee, tuition fee and } \\
\text { miscellaneous fee: } 4000-6000 \text { RMB per } \\
\text { year together. } \\
\text { 2. They require a lot of certificates } \\
\text { such as parents' temporary residence } \\
\text { permits, employment certificate, } \\
\text { personal identification cards, } \\
\text { population planning certificate and } \\
\text { social insurance certificate. } \\
\text { 3. Normal rural migrant families could } \\
\text { not afford the schooling in urban public } \\
\text { schools. }\end{array}$ \\
\hline $\begin{array}{l}\text { Private } \\
\text { Schools }\end{array}$ & $\begin{array}{l}\text { 1. Premium facilities and } \\
\text { curriculum are above the national } \\
\text { standard. } \\
\text { 2. Teachers are OK. }\end{array}$ & $\begin{array}{l}\text { 1. Built for the minor aristocratic class } \\
\text { in the urban China. } \\
\text { 2. Tuition is extremely expensive even } \\
\text { for native urban children. }\end{array}$ \\
\hline
\end{tabular}




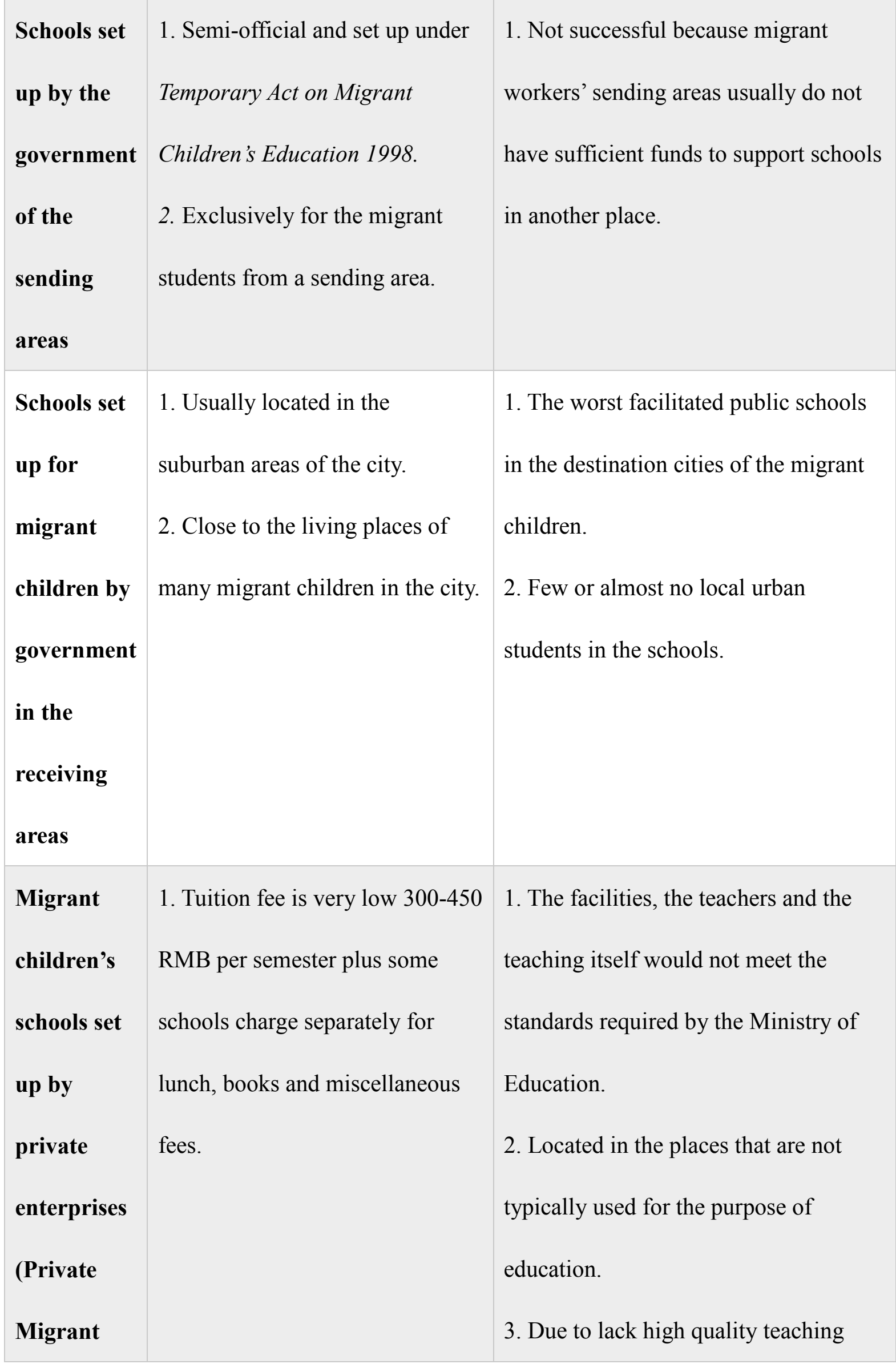


Schools)

staffs, many cannot provide English

course and non-exam courses such as

arts and music.

4. Many schools have been closed by

the government.

*Adopted from Xia (2006) 


\section{APPENDIX 2}

\section{LAWS AND REGULATIONS RELEVANT TO THE SCHOOLING ISSUES OF MIGRANT CHILDREN}

\begin{tabular}{|c|c|c|c|}
\hline Year & Law & Content & Comments \\
\hline 1986 & $\begin{array}{l}\text { Compulsory } \\
\text { Education Law (义 } \\
\text { 务教育法) }\end{array}$ & $\begin{array}{l}\text { 1. Children or teenagers } \\
\text { reach school age should } \\
\text { receive Compulsory } \\
\text { Education. } \\
\text { 2. Free Compulsory } \\
\text { Education and no school fee } \\
\text { should be charged. } \\
\text { 3. The Compulsory } \\
\text { Education is free and no and } \\
\text { the local government under } \\
\text { Education is guaranteed by } \\
\text { no school fee should be } \\
\text { their "Hukou" is registered. } \\
\text { charged. } \\
\text { attend the children should }\end{array}$ & $\begin{array}{l}\text { 1. This law failed to } \\
\text { anticipate the schooling } \\
\text { issues of the large number of } \\
\text { migrant children who did not } \\
\text { stay in their place of origin. }\end{array}$ \\
\hline
\end{tabular}




\begin{tabular}{|c|c|c|c|}
\hline & & government. & \\
\hline 1996 & $\begin{array}{l}\text { Provisional Acts } \\
\text { Regarding the } \\
\text { Education of } \\
\text { School-age } \\
\text { Children of } \\
\text { Floating Population } \\
\text { (城镇流动人口中 } \\
\text { 适龄儿童少年就学 } \\
\text { 办法 (试行) ) }\end{array}$ & $\begin{array}{l}\text { State-run public schools } \\
\text { only enroll children who } \\
\text { hold the local residence } \\
\text { permits }\end{array}$ & $\begin{array}{l}\text { 1. The urban residence } \\
\text { permits were very difficult to } \\
\text { be obtained by the rural } \\
\text { migrant workers at that time. } \\
\text { 2. This law actually } \\
\text { discouraged the rural migrant } \\
\text { children to attend public } \\
\text { schools in the city areas. }\end{array}$ \\
\hline 1998 & $\begin{array}{l}\text { Temporary } \\
\text { Regulation on the } \\
\text { Schooling of the } \\
\text { Migrant Children } \\
\text { (流动儿童少年就 } \\
\text { 学暂行办法) }\end{array}$ & $\begin{array}{l}\text { 1. Governments at both the } \\
\text { migrant origin and } \\
\text { destination have the } \\
\text { responsibility of providing } \\
\text { education to migrant } \\
\text { children. } \\
\text { 2. Migrant children who do } \\
\text { not have guardians in their } \\
\text { place of origin can } \\
\text { temporarily attend the public } \\
\text { or private schools in their }\end{array}$ & $\begin{array}{l}\text { 1. This law allows the } \\
\text { destination cities government } \\
\text { to charge Temporary School } \\
\text { Fee, Sponsor Fee, and other } \\
\text { exorbitant fees. } \\
\text { 2. These fees could be as high } \\
\text { as } 2000 \text { to } 5000 \text { RMB per } \\
\text { semester and these fees are } \\
\text { unaffordable for most of the } \\
\text { migrant children's families } \\
\text { with low income. }\end{array}$ \\
\hline
\end{tabular}




\begin{tabular}{|c|c|c|c|}
\hline & & destination cities. & \\
\hline 2001 & $\begin{array}{l}\text { Decision on the } \\
\text { Improving and } \\
\text { Reforming on the } \\
\text { Basic Education } \\
\text { (关于基础教育改 } \\
\text { 革与发展的决定 } \\
\text { 2001) }\end{array}$ & $\begin{array}{l}\text { 1. Migrant children should } \\
\text { be placed under the } \\
\text { jurisdiction of the } \\
\text { government of the } \\
\text { destination cities, should } \\
\text { mainly attend local urban } \\
\text { public schools. } \\
\text { 2. The local governments } \\
\text { should take measures to } \\
\text { guarantee the education } \\
\text { rights of migrant children in } \\
\text { the urban areas (两为主政 } \\
\text { 策) }\end{array}$ & $\begin{array}{l}\text { This decision encouraged the } \\
\text { local urban destination } \\
\text { government to tackle the } \\
\text { schooling issues of the rural } \\
\text { migrant children. }\end{array}$ \\
\hline 2003 & $\begin{array}{l}\text { Suggestions on } \\
\text { Education of the } \\
\text { Migrant Children } \\
\text { (关于进一步做好 } \\
\text { 进城务工就业农民 } \\
\text { 子女义务教育工作 } \\
\text { 的意见)” }\end{array}$ & $\begin{array}{l}\text { 1. These suggestions } \\
\text { required the urban public } \\
\text { schools to enroll as many } \\
\text { migrant children as they } \\
\text { could } \\
2 . \text { These regulations } \\
\text { established that local }\end{array}$ & $\begin{array}{l}\text { 1. These suggestions caused } \\
\text { substantial resistance on the } \\
\text { city local governments to the } \\
\text { implementation of this policy. }\end{array}$ \\
\hline
\end{tabular}




\begin{tabular}{|c|c|c|}
\hline & & $\begin{array}{l}\text { government has the } \\
\text { obligation to education all } \\
\text { children residing in the } \\
\text { urban areas regardless of } \\
\text { where their family's } \\
\text { household registration } \\
\text { certificates are registered. } \\
\text { 3. The suggestions required } \\
\text { the local urban destination } \\
\text { government to allocate a } \\
\text { special budget for the } \\
\text { compulsory education of the } \\
\text { rural migrant children in the } \\
\text { cities exclusively. }\end{array}$ \\
\hline 2006 & $\begin{array}{l}\text { new Compulsory } \\
\text { Education Law }\end{array}$ & $\begin{array}{l}\text { 1. The migrant children can } \\
\text { attend the public schools in } \\
\text { other places than their } \\
\text { Household Registration } \\
\text { indicates. } \\
\text { 2. The local urban } \\
\text { government should provide } \\
\text { the rural migrant children }\end{array}$ \\
\hline
\end{tabular}




\begin{tabular}{|c|c|c|c|}
\hline & & $\begin{array}{l}\text { with the equal educational } \\
\text { opportunity to the local } \\
\text { urban students. }\end{array}$ & \\
\hline 2006 & $\begin{array}{l}\text { The Central } \\
\text { Government's } \\
\text { Suggestions on } \\
\text { Solving the } \\
\text { Multiple Issues of } \\
\text { Migrant Workers } \\
\text { (国务院关于解决 } \\
\text { 农民工问题的若干 } \\
\text { 意见) }\end{array}$ & $\begin{array}{l}\text { 1. The destination urban } \\
\text { government should shoulder } \\
\text { the responsibility to educate } \\
\text { migrant children in the urban } \\
\text { area. } \\
\text { 2. The local urban government } \\
\text { should enroll migrant children } \\
\text { in the local public school } \\
\text { system and that their education } \\
\text { budget should also provide for } \\
\text { schooling Fee and other fees } \\
\text { the compulsory education of } \\
\text { should treat migrant students } \\
\text { rural migrant students in the } \\
\text { cities. } \\
\text { equally and Teme urban public schools }\end{array}$ & $\begin{array}{l}\text { children equal schooling } \\
\text { opportunities to receive } 9 \\
\text { years compulsory education } \\
\text { in the destination cities. }\end{array}$ \\
\hline 2010 & National Long-term & 1. This plan not only & 1. This law began to consider \\
\hline
\end{tabular}




\begin{tabular}{|c|c|c|}
\hline $\begin{array}{l}\text { Plan for Education } \\
\text { Reform and } \\
\text { Development (国家 } \\
\text { 中长期教育改革和 } \\
\text { 发展规划纲要 } \\
\text { 2010-2020) }\end{array}$ & $\begin{array}{l}\text { on the migrant children: "the } \\
\text { destination urban government } \\
\text { should take a main } \\
\text { responsibilities on the } \\
\text { provision of education for the } \\
\text { migrant children, and the } \\
\text { migrant children should mainly } \\
\text { attend the urban public schools } \\
\text { in their destination cities (两为 } \\
\text { Exam in their destination cities } \\
\text { 主政策)". } \\
\text { 2. It required the local urban } \\
\text { government to work out plans } \\
\text { for the migrant children to sit } \\
\text { Exam and College Entrance }\end{array}$ & $\begin{array}{l}\text { migrant children to attend } \\
\text { colleges and universities in } \\
\text { their destination cities. }\end{array}$ \\
\hline
\end{tabular}




\section{REFERENCES}

Beijing Youth Newspaper (2012). The whereabouts of the migrant children after their schools were closed (北京农民工子弟学校关停之后学生去向). 10 August. Online. Retrieved from http://edu.people.com.cn/GB/216982/17075861.html. Accessed Date: February 2, 2014.

Berry, J. (2011). Property taxes \& public education funding: Inequality in the system. Retrieved from

http://www.academia.edu/912843/Property_Taxes_and_Public_Education_Funding_Inequ ality_in_the_System.

Bi, Y. H. \& Szente, J. (2010). Education of young Chinese migrant children: challenges and prospects. Early Childhood Education Journal. 37, 477-482.

Brown University (2014). Culturally responsive teaching. Retrieved from http://www.brown.edu/academics/education-alliance/teaching-diverse-learners/.

China Education Online (2012). The Specifications for the migrant children siting for the National College Entrance Exam (Gaokao) in the place where they reside: Beijing, Shanghai and Guangdong have the highest requirements (全国各省市异地高考方案细则 北上 广 门 槛高 ). Retrieved from http://gaokao.eol.cn/kuai_xun_3075/20121231/t20121231_887965.shtml. Accessed date $3 / 27 / 2014$.

China Education Online (2014). Beijing forwarded the transitory plan for the students from outside to take the College Entrance Exam in Beijing, migrant students who meet certain requirements can take the exam in Beijing, but need to return to their hometown to take part in the college admitting process in 2014 (北京出台异地高考过渡方案: 满足条件 2014 年 可 借 考 ). http://gaokao.eol.cn/zui_xin_dong_tai_2933/20121231/t20121231_888022.shtml

China News Network (2013). 17 provinces announced the yearly average income of the residents: Beijing residents' average income is 36,469 yuan per year (17 省份公布去年居民收入: 北京人均收入 36469 元). Retrieved from: http://news.qq.com/a/20130125/000303.htm.

Chinese Government (2006). The Central Government's Suggestions on Solving the Multiple Issues of Migrant Workers (国务院关于解决农民工问题的若干意见). Retrieved from http://www.gov.cn/jrzg/2006-03/27/content_237644.htm.

Chinese Government (2010). The national long-term plan for the education reform and development 2010-2020 (国家中长期教育改革和发展规划纲要 2010-2020). Retrieved from http://www.gov.cn/jrzg/2010-07/29/content_1667143.htm. 
Chinese Government (2013). Compulsory education ( 义 务教育). Retrieved from http://www.gov.cn/test/2013-10/29/content_2517462.htm. Accessed date 4/10/2014

College Review (2014). The History of Historically Black Colleges and Universities. Accessed from http://www.collegeview.com/articles/article/the-history-of-historically-blackcolleges-and-universities. Accessed date: 3/27/2014.

Cui, C. Y. (2003). Removing the discriminations towards the migrant children attending schools ( 破除对进城农民工子女的就学歧视). Retrieved from http://www.china.com.cn/chinese/zhuanti/mingong/349845.htm. Accessed date: February $3,2014$.

Dewey, J. (1916). Chapter4: Education as growth. Democracy and Education (pp.25, 30). Retrieved from manybooks.net.

Du, K. W. (2014), 30 provinces and municipal cities solved the problem of College Entrance Exam for the migrant children in the cities in 2014 (2014 年 30 个省区市解决随迁子女 异地高考 ). Retrieved from http://gb.cri.cn/42071/2014/02/20/5951s4431488.htm. Accessed date: March 22, 2014.

Du, Y. B. (2012). Education Ministry: solving the migrant children' s problem of taking the college entrance exam in their destination cities should not influence the benefits of the Beijing and Shanghai local students(教育部: 解决异地高考不能影响京沪考生权益). Retrieved from http://edu.163.com/12/0305/10/7RQU11C600294JD0.html. Accessed date: $3 / 27 / 2014$.

Education Week (2004). Tracking. Retrieved from http://www.edweek.org/ew/issues/tracking/. Accessed date: 4/11/2014.

$\mathrm{Fu}, \mathrm{Y}$. (2011). Education as a means of integration into the city: Migrant children in the government-sponsored honghua school in Chengdu, China. (Order No. 3492791, School of Intercultural Studies, Biola University). ProQuest Dissertations and Theses, 242. Retrieved from http://search.proquest.com/docview/920664469?accountid=14244. (920664469).

Gay (2000). Culturally responsive teaching. Retrieved from http://www.intime.uni.edu/multiculture/curriculum/culture/teaching.htm.

Goodburn, C. (2009). Learning from migrant education: a case study of the schooling of rural migrant children in Beijing. International Journal of Educational Development. 29, 495504

Kunming Daily (2014). Don't put migrant children in a separate classroom (别给农民工子女 单独编班). Retrieved from http://roll.sohu.com/20140309/n396275451.shtml. Accessed date: March 15, 2014. 
Kwong, J. (2004). Research report: education migrant children: Negotiations between the state and civil society. The China Quarterly. 180, 1073-1088.

Kwong, J (2011). Education and identity: the marginalization of migrant youths in Beijing. Journal of Youth Studies. 14(8), 871-883.

Law Library (2005). The Central Government's Decisions on amending “Additional Education Tax” (国务院关于修改〈征收教育费附加的暂行规定〉的决定. Accessed from http://www.law-lib.com/law/law_view.asp?id=99771.

Li, P. (2013). A review of household registration system reform in the past 50 years, changes of the household management policy in new China (户籍改革 50 年回眸, 新中国户籍管理 制度 的变 迁 ). Online. Retrieved from http://news.ifeng.com/history/zhongguoxiandaishi/special/dxpsd1/detail_2013_01/18/213 46278_1.shtml. Accessed at: February 3, 2014.

Li, Y. (2010). Progress in education for the children of rural migrant workers. In Yang Dong Ping \& Chai Chun Qing (Eds.), The China Education Year Book 2010, volume 2 (pp.175-187). Leiden Boston Publishing Company.

Liang, Z. \& Chen, Y. P. (2007). The educational consequences of migration for children in China. Social Science Research 36, 28-47.

Liu, Y. J. (1992). The resources of education fund and growth (教育经费的来源和增长). In Liu Y.J. (Ed.), Book of Major Educational Events in China (中国教育大事典 1949-1990). (pp 99).

Lu, Y. \& Zhou, H. (2013). Academic achievement and loneliness of migrant children in China: school segregation and segmented assimilation. Comparative Education Review, 57(1), 85116.

McLoyd, V.C. (1998). Socioeconomic disadvantage and child development: American psychologist, 53(2), 185.

Mi, W. (2008). Interventions to the family education problems of the migrant children and social work: reflections to investigations of the migrant children's families (农民工流动子女家 庭教育问题与社会工作的介入: 对成都市郊农民工家庭调查的思考). Legal System and Society (法制与社会), 9, 282-283.

Mok, K. H., Kwong Y. C. \& Guo, Y. (2011). Transforming from economic power to soft power: challenges for managing education for migrant workers' children and human capital in Chinese cities. Asia Pacific Journal of Education. 31(3), 325-344. 
Montgomery, J. L. (2012). The inheritance of inequality: Hukou and related barriers to compulsory education for China's migrant children. Pacific Rim Law \& Policy Journal. 21(3).

National Bureau of Statistics of China. (2009). Statistical communique of People's Republic of China on the national economic and social development. Retrieved from www.stats.gov.cn/tjgb

Nan Guo Zao Bao (2012). Guangxi Province used special fund to support the education of migrant children (广西专项资金大力支持进城务工人员随迁子女教育). Retrieved from http://www.naradafoundation.org/sys/html/lm_27/2012-05-11/164754.htm.

Nieto, S. (1996). Affirming diversity: The sociopolitical context of multicultural education (2nd Ed.). White Plains, NY: Longman.

People's Daily (2005). The education investment to the rural area is in short (农村教育投入捉 襟 见 肘 ). (2005, 13). Retrieved from http://www.people.com.cn/GB/paper2836/14453/1285350.html.

Rong, X. L., \& Preissle, J. (2009). Models of immigrant incorporation. In Rong, X. L. \& Preissle, J. (Eds.), Educating immigrant students in the $21^{\text {st }}$ century: What educators need to know (pp. 11-17). California: Corwin Press.

SCAU, College of Public Management (2011). The changes of migrant children education (农 民工 子女义务教 育 政策文本的演变). Retrieved from http://xy.scau.edu.cn/gongguan/ggzc/Article/zcwk/201103/2.html

Taylor, R. W. (2010). The role of teacher education programs in creating culturally competent teacher: a moral imperative for ensuring the academic success of diverse student populations. Multicultural Education, 17(3), 24-28.

Tian, H.S. \& Wu, N. (2008). An investigation report on the education status of migrant children (进城务工随迁子女教育状况调查报告). Retrieved from http://www.nies.net.cn/cb/bg/201203/P020120331410552264357.doc. Accessed at: 8 February.

The Compulsory Education Law of China (2006). Retrieved from http://www.gov.cn/flfg/200606/30/content_323302.htm.

The Compulsory Education Regulations of Hubei Province (2010). Retrieved from http://baike.baidu.com/view/5399410.htm

Xia, C. L. (2006). Migrant children and the right to compulsory education in China. Asia-Pacific Journal on Human Rights and the Law. 2, 29-74. 
Xian Dai Kui Bao (2013). The Jiangsu Province forwarded 30 million RMB budget to help the schooling of the migrant children (江苏财政补助 3000 万元帮农民工随迁子女上学). Retrieved from http://jiangsu.sina.com.cn/news/m/2013-09-26/072873567.html.

Xiao, A. W. (2013). Thoughts and proposal on equity of China's rural compulsory education. Asian Agricultural Research. 5(8): 100-103.

Xiao, Y. (2011). The education of migrant workers' children in china: Lived inequities and policies. (Order No. MR81791, University of Calgary (Canada)). ProQuest Dissertations and Theses, 243. Retrieved from http://search.proquest.com/docview/920012513?accountid=14244. (920012513).

Xinhua News Agency (2014). 30 provinces and municipal cities solved the problem of College Entrance Exam for the migrant children in the cities in 2014 (2014 年 30 个省区市解决随 迁子女异地高考). Retrieved from http://gb.cri.cn/42071/2014/02/20/5951s4431488.htm. Accessed date: March 22, 2014.

Xiong, Y. H. \& Yang, X. G. (2012). The influences of school types on the migrant children's world view and their ways of behaving: based on the field-work study in Shanghai (学校 类型对农民工子女价值观与行为方式的影响：基于上海的实证研究). Youth Research （青年 研究）， 1，71-96. Retrieved from http://www.sirpa.fudan.edu.cn/picture/article/56/98/ed/6111b7b047da8ed85bccfce13af1/f 1a615fe-e041-4192-ad63-58ab01fc3cc1.pdf .

Ye, L. (2012), why should not solely stress on the benefits of the Beijing and Shanghai College Entrance Examination takers in order to solve the problem of college entrance examination migrants (解决异地高考不能偏袒京沪考生的权益). Retrieved from http://edu.163.com/special/njd28/. Accessed date 3/27/2014.

Yinghu, B. (2010). Education of young Chinese migrant children: Challenges and prospective. Early Childhood Education Journal. 37, 477-482.

Yiu, L. (2014). Access and equity for rural migrant in Shanghai. Accessed from 2014 AERA annual conference. Accessed date: 4/4/2014.

Yuan, L. S. (2010). An analysis to the governmental financial policy for the compulsory education of the migrant children (农民工子女义务教育经费负担政策分析). Retrieved from http://neibu.nies.net.cn/snxx/wenxian/snxx_20101126093456_11074.html.

Yuan, G. R. (2012). The migrant students must meet 3 requirements in order to be able to sit for the College Entrance Exam in their destination cities (异地高考设 3 大准入条件). Retrieved from http://news.xinhuanet.com/edu/2012-09/07/c_123682904.htm.

Wang, L. \& Holland, T. (2011). In searching of education equity for the migrant children of Shanghai. Comparative Education. 47(4), 471-487. 
Zhang, S. L. \& Lu, S. Q. (2004). Urban/rural disparity and migrant children's education. Chinese Education and Society. 37(5).

Zhu, J. H. (2013). The total number of migrant workers in China has been grown to more than 260 million (我国 农民工总数超 2.6 亿). Retrieved from http://politics.people.com.cn/n/2013/0528/c1001-21635235.html. Accessed date: $5 / 28 / 2014$.

Zhu, M. H. (2001). The education problems of migrant children in Shanghai. Child Welfare. $80(5)$.

Zhu, L. (2014). The children's department of Women's Association joined with Youth Center of Beijing to conduct a research project on migrant children's family education (北京市妇联 儿童部和青少年中心联合开展 “北京农民工子女家庭教育指导服务模式研究” 课题 研究). Retrieved from http://www.zcpi.org/a/news/ZhichengNews/2014/01/1023.html. Accessed date 4/21/2014. 